\title{
Effect of processing on the texture and structure of raspberry (cv. Heritage) and blackberry (cv. Thornfree)
}

María Beatriz Sousa · Wenceslao Canet · María Dolores Alvarez $(\bowtie) \cdot$ María Estrella Tortosa

M. B. Sousa

Departamento Tecnologia dos Produtos Agrários, Estação Agronómica Nacional, Quinta do Marquês, 2784-505 Oeiras, Portugal

W. Canet $\cdot$ M. D. Alvarez $(\bowtie)$

Department of Plant Foods Science and Technology, Instituto del Frío-CSIC, José de Novaís no.10, 28040 Madrid, Spain

M. E. Tortosa

Department of Plant Biology, Escuela Técnica Superior de Ingenieros Agrónomos, U.P.M., Ciudad Universitaria s/n, 28040 Madrid, Spain

M. D. Alvarez

Phone: +34-91-549-23-00

Fax: +34-91-549-36-27

E-mail: ifrat44@if.csic.es 
Abstract This paper reports separate studies of the effect of pre-treatments $\left(\mathrm{CaCl}_{2}\right.$, low methoxyl pectin (LMP), and combined solutions) and the effect of freezing method (at 4 different rates) and thawing mode (at 2 different rates) on objective parameters, structure and sensory characteristics of fresh raspberries and blackberries. After that, the effect of a complete freezing process combining the best pre-treatments with the best freezing/thawing conditions found for each fruit was investigated. Kramer Shear Cell (KSC), back extrusion, compression and multiple penetration tests were used to measure fruit texture objectively. For calcium and LMP pre-treatments, which were applied separately, texture parameters were significantly higher in samples treated at the highest concentrations $\left(100 \mathrm{mM}\right.$ of $\mathrm{CaCl}_{2}$ for both fruits and 0.3 and $3 \%$ of LMP for raspberry and blackberry respectively) compared to fresh controls. Blackberry structure was more susceptible than raspberry structure to the effect of pre-treatments. For the combined pre-treatments, the highest texture parameters were found in the samples treated with $\mathrm{CaCl}_{2}(100 \mathrm{mM})$ and $\mathrm{LMP}(0.1 \%)$ in the case of raspberries and $\mathrm{CaCl}_{2}(100 \mathrm{mM})$ and LMP $(3 \%)$ in the case of blackberries. Combined pre-treatment did not increase firmness with respect to that of samples treated only with calcium, which indicates that $\mathrm{CaCl}_{2}$ preserved the raspberry structure more efficiently during processing. Fruits frozen by forced convection with liquid nitrogen vapour at $-40{ }^{\circ} \mathrm{C}$ were significantly firmer. Raspberries should be thawed at $5{ }^{\circ} \mathrm{C}$, whereas blackberries may be thawed at room temperature. Sensory analysis showed that the blackberry structure was more resistant to freezing. In both fruits, over the complete process parameter values were again highest in the samples treated with $100 \mathrm{mM} \mathrm{CaCl}$, applied either separately or in combination with LMP. In raspberry, panellists detected no significant differences between sensory texture parameters of the different samples, and in blackberry panellists found no significant differences between any of the sensory characteristics. Multiple penetration maximum force $\left(F_{\mathrm{MP}}\right)$ was the 
parameter that best expressed product firmness for both fresh and frozen raspberries, whereas compression slope $\left(S_{\mathrm{C}}\right)$ best reflected changes in blackberries. SEM mainly corroborated results from objective texture parameters.

Keywords Raspberry; Blackberry; Protective pre-treatments; Freezing and thawing rates; Texture; SEM; Sensory analysis 


\section{Introduction}

Texture is one of the organoleptic quality attributes appreciated by the consumer of fruits, and the major contributor to the texture of fresh fruits is cell turgor pressure. Many studies have focused on turgor pressure $[1,2,3,4]$ as the factor that preponderantly controls the stiffness of liquid-filled cells. Turgidity is in fact the characteristic largely responsible for the final degree of firmness in cherries [5]. In delicately textured fruits, freezing causes a loss of turgidity and firmness [6]. During freezing, ice begins to form in the extra-cellular medium and progresses via the cytoplasm when the cell membrane loses permeability [7]. Decompartmentalization caused by ice crystals prevents the return of water to the intracellular medium during thawing, causing loss of turgidity and hence of fruit texture $[8,9]$. The freezing rate determines the size of ice crystals that form, and this in turn determines the degree of structural damage, which produces a change in the rheological parameters of the tissue [10]. A number of authors have noted that fast freezing rates positively affect the texture of fruits, including cherries [5], blueberries and blackberries [11], raspberries [12, 13] and strawberries [14].

Also, in order to enhance fruit and vegetable firmness and attenuate any freezing-induced loss of texture, thermal or calcium pretreatments $[6,15,16]$ have been proposed that preserve firmness. The effect of calcium on vegetable texture has been attributed to the formation of calcium bridges between galacturonic acid residues. McFeeters and Fleming [17] suggested that the textural effects of calcium were a result of calcium binding at sites other than pectic carboxyl groups. Application of calcium treatments increased firmness and pectinesterase activity in frozen sweet cherries $[6,18]$. In calcium-treated cherries, a decrease in the degree of pectin esterification has been reported, and an increase in both the EDTA-soluble pectin 
fraction and the $\mathrm{Ca}^{2+}$ cation content in the cell wall [6]. The calcium-pectin complex formed acts as an intracellular cement to give firmness to vegetable tissues. Addition of low methoxyl pectin augmenting de-esterification of pectic material may facilitate formation of divalent bridges between residues of galacturonic acid attached to adjacent pectic chains in presence of $\mathrm{Ca}^{2+}$ cations.

The term "firmness of fruit" is commonly used to describe a parameter assessed by means of empirical mechanical tests and understood as an attribute that ought to be maintained during storage and processing [19]. Firmness, interpreted as a mechanical response intrinsic to the fruit structure, is influenced by the stage of physiological development, degree of ripeness, damage and identification, fibrousness and turgidity [5]. A variety of methods have been used to evaluate these characteristics, and various interpretations have been made of mechanical parameters. Santerre et al. [20] designed a multiple stoning cell (five units) for use on texturometers. Comparing these results with the results from a test using the Kramer Shear Cell, they concluded that a multiple test was required to assess the texture of cherries.

The objectives of the current study were: (1) to determine the effect of the pre-treatment with calcium, low methyl pectin and combined solutions on the texture and structure of fresh raspberries and blackberries; (2) to investigate the effect of freezing and thawing rates on the texture, structure and sensory characteristics of both fruits and to find the best conditions for each one; (3) to determine the effect of the pre-treatment with calcium, low methyl pectin and combined solutions on the texture, structure and sensory characteristics of frozen/thawed raspberries and blackberries; and (4) to find the mechanical parameters that best express the firmness of both fresh and frozen fruits. 


\section{Materials and methods}

Plant material. Raspberry fruits (Rubus idaeus L. cv. Heritage) and blackberry fruits (Rubus fruticosus L. cv. Thornfree) were obtained from commercial orchards in the region of Cova da Beira, (Covilhã, Portugal), and harvested at the commercial maturity stage. Both fruits were collected manually and brought to the Estação Agronómica Nacional (Oeiras) within 12 h after harvest via refrigerated transport. On arrival, undamaged fruit was selected and stored in a chamber $\left(2{ }^{\circ} \mathrm{C}\right.$ and $90 \%$ relative humidity) and were kept there for a maximum of 5 days until the experiments were carried out [21]. Although the experiments started the same day of purchase, implementation of the complete study required fruits from two successive crop years. The raspberry fruits used in this study had weights (g) within the confidence interval $(1.542 \leq \mu \leq 2.118) ; P \leq 0.01$, whereas the blackberry fruits had weights $(\mathrm{g})$ within the confidence interval $(2.349 \leq \mu \leq 2.711) ; P \leq 0.01$.

Protective pre-treatments. To study the effect of all the pre-treatments (either applied separately or in combination) on the texture and structure of raspberries, fruits belonging to the first crop year were used. In the case of blackberries, fruits belonging to the first crop year were used to study the effect of the pre-treatments applied separately, and fruits belonging to the second crop year were used to study the effect of the combined treatments. Fruits were selected according to their weight and appearance (ripeness and colour) and cleaned by means of a flow of cold air to remove undesirable materials. After selection and cleaning, samples of both fruits were divided into eleven experimental units. Three units were set aside to study the effect of calcium treatment (with concentrations of 1, 10 and $100 \mathrm{mM}$ for both fruits). Another three units were used to study the effect of the low methoxyl pectin (LMP, Genu pectin type LM 101 AS) treatment (with concentrations of $0.1,0.2$ and $0.3 \%$ for the raspberry and of 1,2 and $3 \%$ for the blackberry). Four experimental units were subjected to combined solutions of calcium and LMP (with concentrations of $\mathrm{CaCl}_{2}, 1 \mathrm{mM}+\mathrm{LMP}, 0.1 \% ; \mathrm{CaCl}_{2}, 1 \mathrm{mM}+$ LMP, $0.3 \% ; \mathrm{CaCl}_{2}, 100 \mathrm{mM}+\mathrm{LMP}, 0.1 \% ; \mathrm{CaCl}_{2}, 100 \mathrm{mM}+\mathrm{LMP}, 0.3$ for raspberry and of $\mathrm{CaCl}_{2}, 10 \mathrm{mM}+$ LMP, $1 \% ; \mathrm{CaCl}_{2}, 10 \mathrm{mM}+\mathrm{LMP}, 3 \% ; \mathrm{CaCl}_{2}, 100 \mathrm{mM}+\mathrm{LMP}, 1 \% ; \mathrm{CaCl}_{2}, 100 \mathrm{mM}+\mathrm{LMP}, 3 \%$ for blackberry). The last experimental unit, which was left untreated, was used as a control in both fruits. All the protective pre-treatments were carried out by pulverizing the samples with the different solutions using an 
atomiser Hozelock (Mod. 4403 Premier, Haddenham, Buckinhamshire). After pulverisation, all samples were immediately air-dried and stored at $5^{\circ} \mathrm{C}$ until the various assays [22].

Freezing and thawing processes. To study the effect of freezing and thawing rates on the texture and structure of raspberries and blackberries, fruits belonging to the first crop year were used. After selection and cleaning as indicated above, the fruits were divided into eight experimental units. For each product, freezing and thawing processes were carried out using four different freezing rates and two thawing rates. In both fruits, the highest freezing rates were achieved by directly immersing the fruits in liquid nitrogen until the thermal centres of the fruits reached $-18{ }^{\circ} \mathrm{C}\left(R_{\mathrm{f}}=309 \pm 3{ }^{\circ} \mathrm{C} \min ^{-1}\right.$ for raspberry and $R_{\mathrm{f}}=140 \pm 2{ }^{\circ} \mathrm{C} \min ^{-1}$ for blackberry respectively). Very high rates were also achieved for both products by freezing the samples by means of a combination of immersion followed of vapours of liquid nitrogen at $\approx-88^{\circ} \mathrm{C}$ until the thermal centres of the fruits reached -18 ${ }^{\circ} \mathrm{C}\left(R_{\mathrm{f}}=105 \pm 3{ }^{\circ} \mathrm{C} \min ^{-1}\right.$ for raspberry and $R_{\mathrm{f}}=32 \pm 2{ }^{\circ} \mathrm{C} \min ^{-1}$ for blackberry respectively $)$. The third and fourth groups of experimental units were frozen by forced convection with liquid nitrogen vapour at $-24{ }^{\circ} \mathrm{C}\left(R_{\mathrm{f}}\right.$ $=1.3 \pm 0.15{ }^{\circ} \mathrm{C} \mathrm{min}-1$ for raspberry and $R_{\mathrm{f}}=1 \pm 0.1{ }^{\circ} \mathrm{C} \mathrm{min}-1$ for blackberry respectively $)$ and at $-40{ }^{\circ} \mathrm{C}\left(R_{\mathrm{f}}=3.3 \pm 0.3\right.$ ${ }^{\circ} \mathrm{C} \min ^{-1}$ for raspberry and $R_{\mathrm{f}}=2.2 \pm 0.2{ }^{\circ} \mathrm{C} \mathrm{min}^{-1}$ for blackberry respectively) until the thermal centres of the fruits reached $-18{ }^{\circ} \mathrm{C}$, using an Air Liquid type CCF 40 cabinet. Once frozen, fruits were packed into stratified polyethylene bags $(500 \mathrm{~g} / \mathrm{bag})$ and sealed with a low vacuum of -0.5 bar to prevent oxidation and damage from surface dehydration. Half of the samples were quickly thawed at room temperature $+20 \pm 2{ }^{\circ} \mathrm{C}$ until their thermal centres reached $+5{ }^{\circ} \mathrm{C}\left(R_{\mathrm{t}}=0.18 \pm 0.8^{\circ} \mathrm{C} \min ^{-1}\right.$ for raspberry and $R_{\mathrm{t}}=0.12 \pm 1{ }^{\circ} \mathrm{C} \min ^{-1}$ for blackberry respectively $)$. The other half were slowly thawed in the sealed bags by forced air convention at $+5{ }^{\circ} \mathrm{C}$ until their thermal centres reached $+5{ }^{\circ} \mathrm{C} \quad\left(R_{\mathrm{t}}=0.05 \pm 0.01{ }^{\circ} \mathrm{C} \min ^{-1}\right.$ for raspberry and $R_{\mathrm{t}}=0.04 \pm 0.01{ }^{\circ} \mathrm{C} \min ^{-1}$ for blackberry respectively) using a Sellecta stove (Hotcold-M, Barcelona, Spain) with the temperature regulator set between 0 and $9{ }^{\circ} \mathrm{C}$. For calculation of the freezing and thawing rates in the different modes, media and fruit temperatures were monitored by T-type thermocouples using a hardware and software system that permitted data gathering and storage [23]. The freezing and thawing rates given are the mean values of four different processes conducted under the same conditions. 
Complete freezing process. To study the effect of the complete freezing process (combining the best pretreatments with the best freezing and thawing rates), fruits belonging to the second crop year were used. After selection and cleaning as indicated above, raspberries were divided into eight and blackberries into seven experimental units. For each product, two units were set aside to study the effect of calcium treatment prior to freezing (with concentrations of 1 and $100 \mathrm{mM}$ for raspberry and of 10 and $100 \mathrm{mM}$ for blackberry). Another two units were used to study the effect of the low methoxyl pectin (LMP, Genu pectin type LM 101 AS) treatment prior to freezing (with concentrations of 0.1 and $0.3 \%$ for raspberry and of 1 and $3 \%$ for blackberry). Two more experimental units were subjected to combined solutions of calcium and LMP (with concentrations of $\mathrm{CaCl}_{2}, 100 \mathrm{mM}+\mathrm{LMP}, 0.1$ and $0.3 \%$ for raspberry and of $\mathrm{CaCl}_{2}, 100 \mathrm{mM}+\mathrm{LMP}, 1$ and $3 \%$ for blackberry). After pre-treatments, all experimental units were frozen by forced convection with liquid nitrogen vapour at -40 ${ }^{\circ} \mathrm{C}\left(R_{\mathrm{f}}=3.3 \pm 0.3{ }^{\circ} \mathrm{C} \min ^{-1}\right.$ for raspberry and $R_{\mathrm{f}}=2.2 \pm 0.2{ }^{\circ} \mathrm{C} \mathrm{min}^{-1}$ for blackberry respectively $)$ and then packed as described above. Raspberry samples were then thawed by forced convention air at $+5{ }^{\circ} \mathrm{C}\left(R_{\mathrm{t}}=0.05 \pm 0.01{ }^{\circ} \mathrm{C} \min ^{-}\right.$ $\left.{ }^{1}\right)$, while blackberries were thawed at room temperature $+20 \pm 2{ }^{\circ} \mathrm{C}\left(R_{\mathrm{t}}=0.12 \pm 1{ }^{\circ} \mathrm{C} \min ^{-1}\right)$. In this study, two additional experimental units were used as controls for raspberry. The first consisted of untreated fruits (fresh material) directly frozen $\left(R_{\mathrm{f}}=3.3 \pm 0.3{ }^{\circ} \mathrm{C} \min ^{-1}\right)$, packed and thawed $\left(R_{\mathrm{t}}=0.05 \pm 0.01{ }^{\circ} \mathrm{C} \min ^{-1}\right)$. The second consisted of fresh material that was treated with sucrose before freezing and thawing. Sucrose is usually added in the preservation process for confectionery [14]. Food grade granulated sucrose $(100 \mathrm{~g} / 100 \mathrm{~g})$ was used as osmotic medium. Raspberry samples were mixed with sucrose by hand in order to obtain a sample/total weight ratio of $25 \mathrm{~g} / 100 \mathrm{~g}$. The osmotic process went on for $3 \mathrm{~h}$ at $20{ }^{\circ} \mathrm{C}$ in a water-bath. Thorough contact between sugar and fruit was maintained by hand mixing them every 30-min. Samples were then frozen, packed and thawed for use as the first control. In the case of blackberry, only one additional experimental unit was used as control, consisting of untreated fruits (fresh material) directly frozen $\left(R_{\mathrm{f}}=2.2 \pm 0.2{ }^{\circ} \mathrm{C} \min ^{-1}\right)$, packed and thawed $\left(R_{\mathrm{t}}=0.12 \pm 1^{\circ} \mathrm{C} \min ^{-1}\right)$.

Instrumental texture measurements. For objective assessment of texture, tests simulating chewing with a Kramer shear cell (KSC), and empirical tests of back extrusion, compression and multiple penetration were performed on a texturometer Lloyd Instruments, mod T5K (J.J. Lloyd Instruments Lda, Southampton, UK). In the case of raspberry, KSC and back extrusion tests were carried out using a $100 \mathrm{~N}$ load cell for the processed samples and a 
$500 \mathrm{~N}$ load cell for the fresh controls; multiple penetration and compression tests were performed using a $50 \mathrm{~N}$ load cell for the processed samples and a $100 \mathrm{~N}$ load cell for the controls. In the case of blackberry, KSC and back extrusion tests were carried out using a $500 \mathrm{~N}$ load cell for the processed samples and a $5000 \mathrm{~N}$ load cell for the fresh controls; multiple penetration and compression tests were performed using a $100 \mathrm{~N}$ load cell for the processed samples and a $500 \mathrm{~N}$ load cell for the controls. KSC tests $(n=5)$ were performed with a Kramer shear cell 10 blade on $100 \pm 1 \mathrm{~g}$ samples of raspberry or blackberry fruits placed on the cell base [24, 25]. For performance of the back extrusion tests $(n=5)$, a flat $90-\mathrm{mm}$ diameter stainless steel plunger was used to penetrate a 100-mm diameter stainless steel cylinder containing $150 \pm 1 \mathrm{~g}$ of raspberries or $120 \pm 1 \mathrm{~g}$ of blackberries. Compression tests $(n=5)$ were performed using a flat 90 -mm diameter stainless steel plunger. The test consisted in placing three raspberry or blackberry fruits on the flat cell base and compressing. Multiple penetration tests $(n=5)$ were performed using a multiple rig. In this test, 26 fruits were simultaneously penetrated by 26 indentations. In all the mechanical tests, the deformation rate was $400 \mathrm{~mm} \mathrm{~min}^{-1}$. The KSC, back extrusion, compression, and multiple penetration force-deformation curves were used to determine four maximum forces, $F_{\mathrm{KSC}}, F_{\mathrm{E}}, F_{\mathrm{C}}$, and $F_{\mathrm{MP}}(\mathrm{N})$, the KSC and back extrusion energies (areas under the curve up to maximum forces), $E_{\mathrm{KSC}}$ and $E_{\mathrm{E}}\left(\mathrm{J} 10^{-2}\right)$, and the compression and multiple penetration curve slopes in the linear zone, $S_{\mathrm{C}}$ and $S_{\mathrm{MP}}\left(\mathrm{N} \mathrm{mm}^{-1}\right)$. All results were expressed by g of dry matter.

Dry matter content. Determinations were made on $20 \mathrm{~g}$ of fruit pulp by drying samples in a Sanyo microwave oven $(900 \mathrm{~W})$ set at 2 position. Samples were weighed every 5 min until a constant weight was attained [26]. Ten determinations were performed for each experimental unit.

Structural examination. Tissue structure was examined by SEM using a Hitachi model S-2500 microscope [19, 27]. Tissue samples were fixed in FAA $\{50$ or $70 \%$ ethyl alcohol $(90 \mathrm{~mL})$, glacial acetic acid $(5 \mathrm{~mL})$, and formaldehyde $(5 \mathrm{~mL})\}$ for $2 \mathrm{~h}$ and dehydrated in increasing concentrations of ethanol, from $70 \%$ to $100 \%$. The samples were immersed once for $15 \mathrm{~min}$ in ethanol concentrations of 70,80 , and $90 \%$ and twice for $1 \mathrm{~h} \mathrm{in} 100 \%$ ethanol. Finally, the specimens were preserved in acetone until processed in a critical-point drier, then mounted and sputter-coated with platinum (400- $\AA$ ) in a P-S1 diode sputtering system metallizer. Photomicrographs were taken with a Mamiya camera using Ilford 6x9 cm FF-4 film. Films were processed following the standard 
method; magnifications were x300, x138 and x21 $(1 \mathrm{~cm}=33.3 \mu \mathrm{m}, 1 \mathrm{~cm}=72.5 \mu \mathrm{m}, 1 \mathrm{~cm}=476 \mu \mathrm{m}$, respectively in most of the micrographs in the present study.

Sensory analysis. An eight-member panel trained for frozen fruits conducted sensory analysis for texture, taste, and colour following a descriptive quantitative method adapted for each product [28]. The sensory characteristics assessed for texture were firmness and juiciness. The sensory characteristics assessed for taste were sweet taste, bitter taste and authentic taste. The sensory characteristics assessed for colour were redness, uniformity and shine. Scores were awarded on a scale of 1-5, in which 1 indicated total absence of the sensory attribute and 5 a very definite attribute.

Statistical analysis. Each experimental unit was repeated twice. For the effect of protective pre-treatments on the different objective parameters of texture, the results were subjected to three different one-way analyses of variance (ANOVA) using MSTAT Version 4.0 (Michigan State University, USA). Three calcium or LMP treatments plus the control $\mathrm{X} 2$ replicates with $7^{\circ}$ of freedom were used for the effect of the pre-treatments applied separately, and four calcium + LMP treatments plus the control X 2 replicates with $9^{\circ}$ of freedom were used for the effect of the combined pre-treatments. For the effect of the freezing and thawing rates on objective parameters and sensory characteristics, results were subjected to multifactor analysis of variance (ANOVA) on 8 freezing/thawing combinations $X 2$ replicates with $15^{\circ}$ of freedom. For the effect of the complete freezing process on objective parameters and sensory characteristics of the fruits, data were tested by one way analysis of variance (ANOVA) using eight process treatments $\mathrm{X} 2$ replicates with $15^{\circ}$ of freedom for raspberry, and seven process treatments X 2 replicates with $13^{\circ}$ of freedom for blackberry. In all the analyses, where there were significant differences individual treatments were compared using the least significant difference test (LSD, 95 and $99 \%$ for sensory attributes and textural parameters respectively).

\section{Results and discussion}

\section{Effect of protective pre-treatments}




\section{[Table 1 will appear here. See end of document.]}

Table 1 shows the mean values of the different texture parameters in the calcium pretreatment at the concentrations chosen for each fruit. In the case of raspberry, the pretreatment significantly affected the values of $\mathrm{KSC}$, back extrusion and multiple penetration maximum forces $\left(F_{\mathrm{KSC}}, F_{\mathrm{E},} F_{\mathrm{MP}}\right)$, and of compression and multiple penetration slopes $\left(S_{\mathrm{C}}\right.$, $\left.S_{\mathrm{MP}}\right)(P \leq 0.01)$. The texture parameter values were highest in the samples treated with 100 $\mathrm{mM}$ of $\mathrm{CaCl}_{2}$, which with the exception of the back extrusion maximum force were significantly higher than the corresponding fresh control values. In the case of blackberry, the effect of the calcium pre-treatments was more significant than for raspberry, with all textural parameters detecting the effect of calcium concentration $\left(P \leq 0.001\right.$, except for $\left.S_{\mathrm{MP}}\right)$. The mechanical resistance of the fruits augmented with increasing calcium concentration, and again the values of all the parameters were highest at the highest concentration of $\mathrm{CaCl}_{2}$; these values were significantly different from and higher than the values obtained for untreated fruits. Increased firmness (mostly apparent in $100 \mathrm{mM} \mathrm{CaCl} 2$ ) in cherries has been attributed to the formation of calcium bridges in the pectic material, caused by a decrease in the degree of esterification of pectins and increases in the pectic fraction soluble in EDTA and the $\mathrm{Ca}^{2+}$ cation content in the cell wall [6]. These authors found that the effect of $\mathrm{CaCl}_{2}$ could even be detected in fruits frozen stored for 6 months and was more apparent after freezing. Therefore, our results suggested that pre-treatment by pulverisation in $100 \mathrm{mM}$ $\mathrm{CaCl}_{2}$ can also prevent loss of firmness in frozen raspberries and blackberries. In the case of raspberry, of all the objective parameters of texture, KSC maximum force $\left(F_{\mathrm{KSC}}\right)$ and the two multiple penetration parameters $\left(F_{\mathrm{MP}}, S_{\mathrm{MP}}\right)$ presented the lowest variability and the lowest values of minimum significant difference (LSD). In the case of blackberry, the compression 
slope $\left(S_{\mathrm{C}}\right)$ and the two penetration parameters $\left(F_{\mathrm{MP}}, S_{\mathrm{MP}}\right)$ presented the lowest variability and the lowest values of LSD. Any mechanical tests used should be independent of sample weight and volume, and the sample preparation should be as non-destructive as possible [5]. We suggest that the best parameters for assessing the firmness of both fruits when pre-treated with calcium are those determined in the multiple penetration tests, which have the advantage of being independent of sample weight and less dependent on sample volume.

\section{[Table 2 will appear here. See end of document.]}

Table 2 shows the effect that the LMP pre-treatment produced on the objective texture parameters of the fruits. In the case of raspberry, the effect of the pre-treatment was significant in back extrusion, compression and multiple penetration maximum force values $\left(F_{\mathrm{E}}, F_{\mathrm{C}}, F_{\mathrm{MP}}\right)$, in back extrusion energy $\left(E_{\mathrm{E}}\right)$ and in compression and multiple penetration slopes $\left(S_{\mathrm{C}}, S_{\mathrm{MP}}\right)(P \leq 0.01)$. Values of compression and multiple penetration parameters were highest in the samples treated with $0.3 \%$ LMP and significantly higher than in the fresh control. As was found with the calcium pre-treatment, the effect of the LMP pre-treatment was more significant in blackberry than in raspberry, and all the textural parameters detected the effect of the LMP concentration $\left(P \leq 0.001\right.$, except for $\left.S_{\mathrm{MP}}\right)$. Increasing LMP concentration was accompanied by increasing mechanical resistance of the fruits. The highest values of all parameters coincided with the highest concentration of LMP (3\%); these values were significantly different from and higher than those recorded in the fresh control. It would seem that blackberry structure was more susceptible than raspberry structure to the effect of the calcium and LMP pre-treatments applied separately. In the case of raspberry, back extrusion energy $\left(E_{\mathrm{E}}\right)$ and multiple penetration maximum force $\left(F_{\mathrm{MP}}\right)$ presented the lowest LSD values of all the parameters. In the case of blackberry, LSD values were lowest for KSC and back 
extrusion energies $\left(E_{\mathrm{KSC}}, E_{\mathrm{E}}\right)$ and multiple penetration maximum force $\left(F_{\mathrm{MP}}\right)$. The maximum force is the multiple penetration test curve parameter that best expresses the firmness of the products; this applies equally to fresh fruits and fruits pre-treated with LMP and has the advantage of being independent of sample weight.

\section{[Table 3 will appear here. See end of document.]}

The effect of the combined calcium and LMP pre-treatment on the texture of the fruits is shown in Table 3. In the case of raspberry, the effect was significant in KSC, back extrusion and multiple penetration maximum force $\left(F_{\mathrm{KSC}}, F_{\mathrm{E}}, F_{\mathrm{MP}}\right)$, in $\mathrm{KSC}$ and back extrusion energies $\left(E_{\mathrm{KSC}}, E_{\mathrm{E}}\right)$ and in compression and multiple penetration slopes $\left(S_{\mathrm{C}}, S_{\mathrm{MP}}\right)(P \leq 0.01)$. Values of the textural parameters were highest in the samples treated with $100 \mathrm{mM} \mathrm{CaCl} 2$ and $0.1 \%$ LMP, although in most cases parameter values were not significantly different from those recorded in the samples treated with $100 \mathrm{mM} \mathrm{CaCl}_{2}$ and $0.3 \%$ LMP. In raspberry, the combined treatments with $100 \mathrm{mM} \mathrm{CaCl}_{2}$ and 0.1 or $0.3 \%$ LMP did not generally increase fruit firmness with respect to samples treated only with calcium (100 mM) (Tables 1 and 3). This result indicates that the calcium pre-treatment was more effective than the LMP pretreatment in preserving the raspberry structure, which it could be expected since low methoxyl pectin requires the presence of multivalent cations to gel [29]. In the case of blackberry, the combined pre-treatment significantly affected KSC, back extrusion and multiple penetration parameters $(P \leq 0.001)$, while its effect on the values of the compression parameters was practically non-significant. In this case, textural parameter values, except for the $E_{\mathrm{KSC}}$, were highest in the samples treated with $100 \mathrm{mM} \mathrm{CaCl}_{2}$ and $3 \% \mathrm{LMP}$. However, it was not possible to compare these values with the values obtained for the pre-treatments

applied separately, since the combined pre-treatments were performed on fruits from a 
different season, and the considerable variation between them was at least partially attributable to different edapho-climatic conditions. In the combined pre-treatment, LSD values were lowest for $\mathrm{KSC}$ and multiple penetration maximum force $\left(F_{\mathrm{KSC}}, F_{\mathrm{MP}}\right)$ in raspberry, whereas in blackberry, LSD values were lowest for KSC and back extrusion energies $\left(E_{\mathrm{KSC}}, E_{\mathrm{E}}\right)$ and multiple penetration maximum force $\left(F_{\mathrm{MP}}\right)$. Again, we suggest that $F_{\mathrm{MP}}$ is the parameter that best expresses product firmness, for both fresh fruit and fruit pretreated with calcium and LMP.

Fig. 1 and Fig. 2 respectively show microphotographs of control samples of raspberry and blackberry epidermis tissue untreated other than in preparation for SEM. Microphotograph 1, 1 shows a linking zone between two drupelets where the surface is covered with small trachomas (bright regions). Trachomas can be seen in more detail in microphotograph 1, 2, where the cell structure appears to be undamaged, with turgid cells and intact cell walls. Microphotograph 1, 3 shows a stoma, whose appearance is characteristic of a living cell. Microphotograph 2, 1 shows a set of aggregated drupelets of fresh blackberry tissue. The appearance is quite similar to the view in microphotograph 1,2, with turgid cells and intact cell walls, which appear to be thicker than in the case of raspberry cells, conferring strong cohesion between cells. Stomas are also visible in the cell structure of fresh blackberry tissue (Microphotograph 2, 2). Fig. 3 shows microphotographs of samples of raspberry epidermis tissue treated with $100 \mathrm{mM} \mathrm{CaCl}_{2}$. The drupelets present high turgidity with strong mutual cohesion, and there is a noticeable presence of calcium deposits. In cherries treated with 1 and $10 \mathrm{mM} \mathrm{CaCl}_{2}$, Marchiner [30] attributed increasing cell turgidity to the protective effect of the calcium, which prevents either membrane degradation or the recovery of selective permeability lost during the ripening process. Fig. 4 shows microphotographs of samples of blackberry epidermis tissue treated with $100 \mathrm{mM} \mathrm{CaCl}_{2}$ and $3 \% \mathrm{LMP}$. Unlike the case of 
fresh blackberry, there are no visible signs of cell damage; the surface is fairly smooth, with ridges and folds created by calcium and low methoxyl pectin.

\section{Effect of freezing and thawing processes}

Multifactorial analysis of variance showed that the freezing method (Fig. 5a-h) significantly affected $(P \leq 0.001)$ all objective texture parameters for thawed raspberry tissue; also, the thawing mode significantly affected both parameters derived from the back extrusion test (Fig. 5b, h), and likewise the compression and multiple penetration maximum forces (Fig. 5c, d) $(P \leq 0.001)$. A significant interaction was found between freezing and thawing rates for all maximum forces, and likewise for the back extrusion energy and multiple penetration slopes. Parameters were highest for freezing by forced convection with liquid nitrogen vapour at -40 ${ }^{\circ} \mathrm{C}\left(R_{\mathrm{f}}=3.3 \pm 0.3{ }^{\circ} \mathrm{C} \min ^{-1}\right)$ and thawing at the slowest thawing rate $\left(R_{\mathrm{t}}=0.05 \pm 0.01{ }^{\circ} \mathrm{C} \min ^{-1}\right)$. The dispersion of means was lowest in multiple penetration maximum force $\left(F_{\mathrm{MP}}\right)$, which is the parameter that best reflects the changes occurring in the turgidity of the raspberry as a result of freezing and thawing. Similarly, analysis of variance showed that the freezing method (Fig. 6a-h) significantly affected all the texture parameters of thawed blackberry tissue, although the level of significance was more heavily dependent on the parameter concerned. The freezing rate most significantly affected $\mathrm{KSC}$, compression and multiple penetration maximum forces, back extrusion energy and compression and penetration slopes $(P \leq 0.001)$. Likewise, the thawing rate significantly affected compression test curve parameters (Fig. 6c, g) $(P \leq 0.001)$, multiple penetration test curve parameters (Fig. 6d, h) $(P \leq 0.01)$ and $\mathrm{KSC}$ and back extrusion energies $(P \leq 0.001)$. In the case of blackberry, the only 
significant interaction was between freezing and thawing rates for back extrusion energy $(P \leq 0.001)$, which means that each effect was independently significant. For blackberries, the highest parameters were again recorded in the samples frozen by forced convection with liquid nitrogen vapour at $-40{ }^{\circ} \mathrm{C}\left(R_{\mathrm{f}}=2.2 \pm 0.2{ }^{\circ} \mathrm{C} \min ^{-1}\right)$, but in this case thawed at the fastest rate $\left(R_{\mathrm{t}}=0.12 \pm 1{ }^{\circ} \mathrm{C} \mathrm{min}^{-1}\right)$. In the case of strawberries, SEM also showed that the structure was better preserved when high freezing or thawing rates were used [14]. In blackberries, the slope of the compression test $\left(S_{\mathrm{C}}\right)$ is the parameter that best reflects changes occurring in the turgidity of the fruits as a result of freezing and thawing.

Fig. 7 compares microphotographs of raspberry tissues frozen and thawed at several of the combinations used with fresh control. Freezing by immersion in liquid nitrogen (microphotographs 7, 2 and 7,3) caused considerable structural damage, tissue distortion and dehydration and cracking or rupture irrespective of the thawing rate. These events caused a loss of turgidity in the fruits and an increase in the \% of dry matter. Loss of turgidity produced softening of the fruit as reflected by the mechanical parameters. It has been stated that one of the principal limitations of fast freezing rates is that a rigid crust forms on the surface of the product, preventing an increase in volume during freezing. This causes tensions to build up in the product, rendering it more liable to crack. Pre-cooling can dramatically reduce static cracking of specimens with soft cores and stones as well, especially at higher freezing rates [10]. The integrity of the parenchymatous tissue cells, which appeared less dehydrated and unruptured, was better preserved with a lower freezing rate $\left(3.3^{\circ} \mathrm{C} \min ^{-1}\right)$, especially at the slowest thawing rate (microphotograph 7,5 ). During the freezing process, ice crystals damage and rupture the parenchymatous tissue cells, so that during thawing the intracellular contents exude through the scar left by the stalk and certain pores which open in 
the cuticle during freezing. This freezing rate may be considered critical in the specific case of raspberry. The microstructure observations were supported by the values of firmness retention indicated and shown above (Fig. 5). The fastest freezing rate produced a less drastic effect on the cellular structure of blackberry tissue (Fig. 8, 1-5). When the tissue was frozen by immersion in liquid nitrogen (microphotographs 8,2 and 8,3 ), there was no apparent cell cracking or rupture, although the cells appeared plasmolysed and there were clear signs of loss of turgidity resulting in loss of tissue rigidity (Fig. 6). As was found in raspberry, a lower freezing rate $\left(2 .{ }^{\circ} \mathrm{C} \mathrm{min}^{-1}\right)$ did little damage to the structure, with hardly any rupturing of cell walls or loss of internal cell pressure (microphotographs 8, 4 and 8, 5). It is generally accepted that quality is better retained with fast than with slow freezing rates [31]. From the results presented, it seems obvious that the ultrarapid freezing of both fruits produced unfavourable effects. In any event, it is important to note that the freezing rates, above 0.83 ${ }^{\circ} \mathrm{C} \min ^{-1}$, attained in samples by means of forced convection with liquid nitrogen vapour at either-24 ${ }^{\circ} \mathrm{C}$ or $-40{ }^{\circ} \mathrm{C}$ may be considered rapid freezing [32]. A freezing-induced alteration in turgidity will cause changes in texture and acceptability of the product [5]; and in effect, of the sensory characteristics assessed in raspberry, when frozen and thawed samples were compared with fresh control, significant differences were found in firmness (LSD=0.30), juiciness ( $\mathrm{LSD}=0.32)$, sweet taste $(\mathrm{LSD}=0.30)$, bitter taste $(\mathrm{LSD}=0.42)$, authentic taste $(\mathrm{LSD}=0.33)$, shine $(\mathrm{LSD}=0.30)$ and uniformity $(\mathrm{LSD}=0.38)$. Panellists detected no effect of the freezing method on the redness of the fruits. (Data are not presented for the sake of brevity.) As expected, fresh control scored highest for firmness and sweet taste, but the lowest for juiciness and bitter taste, which may be explained by the panellists' perceiving intracellular liquids present in the tissue after thawing as a consequence of freezing-induced cell damage. Of the sensory characteristics assessed in blackberry, panellists only detected an 
effect of the freezing process on authentic taste (LSD=0.34) and shine (LSD=0.33). Panellists did not detect a significant difference between the firmness of frozen/thawed fruit and that of fresh control, thus confirming that the blackberry structure is more resistant to freezing processes.

\section{Effect of complete freezing process}

\section{[Table 4 will appear here. See end of document.]}

Table 4 shows the effect of the complete process on average values of texture parameters for both fruits. In the case of raspberry, there was a significant effect on the values of all the parameters $(P \leq 0.001)$. The highest values were recorded in samples treated with $\mathrm{CaCl}_{2}(100$ $\mathrm{mM})$ or with $\mathrm{CaCl}_{2}(100 \mathrm{mM})+\mathrm{LMP}(0.1 \%)$ depending on the parameter considered. The increase in the number of calcium bridges augmented intercellular adhesiveness and strengthened the tissues, preventing freezing-induced loss of firmness in the fruits [6]. In the complete freezing process of raspberry, the positive effect produced on the texture by the $\mathrm{CaCl}_{2}(100 \mathrm{mM})$, applied either separately or combined with LMP, was sustained, so that these samples remained significantly firmer than either of the untreated controls. Parameters for both controls were significantly equal, except for the back extrusion and multiple penetration maximum forces. We may therefore say that under the operating conditions employed, prior treatment with sugar did not greatly alter raspberry tissue structure. In the case of blackberry, the complete process also significantly affected all the texture parameters $(P \leq 0.01)$. The parameters were lowest in the untreated samples, evidencing the positive effect of all the chosen pre-treatments in preventing freezing-induced loss of firmness in this fruit. 
Again, the highest values of the parameters were recorded in the samples treated with 100 $\mathrm{mM} \mathrm{CaCl}_{2}$ applied either separately or in combination with LMP.

\section{[Table 5 will appear here. See end of document.]}

The relationships between texture parameters derived from the same and from different mechanical tests were determined by analysis of correlation (Table 5). In the case of raspberry, the highest correlation between parameters derived from the same test was found between KSC maximum force and KSC energy ( $r=0.952)$; however, there was also a significant correlation between back extrusion $(r=0.925)$, compression $(r=0.780)$ and multiple penetration parameters $(r=0.870)$. This suggests that there could be redundancy among the parameters from the same test; in other words, they may reflect the same effect on fresh and frozen-thawed tissue, so that it is not necessary to measure two parameters from each test. The highest correlations between parameters derived from different tests were found between multiple penetration slope and KSC energy $(r=0.956)$ and between KSC and compression maximum forces $(r=0.946)$. In the case of blackberry, there were fewer correlations between parameters in general terms than in the case of raspberry fruits. Of parameters derived from the same test, the only significant correlations were between KSC maximum force and KSC energy ( $r=0.808)$ and between maximum force and compression slope $(r=0.791)$. The highest correlation between parameters derived from different tests was between back extrusion energy and compression maximum force $(r=0.909)$. LSD values were lowest for multiple penetration maximum force and slope $\left(F_{\mathrm{MP}}, S_{\mathrm{MP}}\right)$ and compression slope $\left(S_{\mathrm{C}}\right)$ in the case of raspberry, and back extrusion energy $\left(E_{\mathrm{E}}\right)$ and compression slope $\left(S_{\mathrm{C}}\right)$ in the case of blackberry. We therefore suggest that for raspberry the multiple penetration maximum parameters $\left(F_{\mathrm{MP}}, S_{\mathrm{MP}}\right)$ best express the firmness of both fresh and processed fruits. As regards the loss of turgidity in blackberries as a result of the complete process, the slope of the 
compression test curve $\left(S_{\mathrm{C}}\right)$ may be the parameter that best reflects the changes occurring in the turgidity of the fruit, besides having the advantage of being independent of sample weight.

Fig. 9 compares microphotographs of raspberry tissues subjected to the complete process at several of the combinations used with fresh control. The appearance of structures of samples directly frozen and thawed in the best conditions determined for raspberry and the appearance of samples subjected to a pre-treatment with $\mathrm{CaCl}_{2}(100 \mathrm{mM})$ prior to freezing/thawing under the same conditions (Fig. 9, 2 and 9, 3) is similar; there are more plasmolysed cells than in fresh control, but cell integrity and turgidity is maintained in spite of the freezing process. The combined pre-treatment prior to freezing (Fig. 9, 4) led to the formation of a thicker film, deposited mainly on the trachomas, which was possibly the reason why some of the texture parameters were highest in the tissue subjected to pretreatment (Table 4). Fig. 10 compares microphotographs of blackberry tissues subjected to the complete process at several of the combinations used with fresh control. Microphotograph 10, 2 shows that although the conditions of freezing and thawing rates were the best of those determined for blackberry, the processing without pre-treatment caused cell plasmolysis and loss of turgidity, even though there are no visible signs of rupture in the cell walls. Tissue structures most closely resemble those of fresh control in samples subjected to the combined pre-treatments (microphotographs 10,5 and 10,6), where the most striking aspect is an enlargement of the cell walls, resulting in higher mechanical strength.

As regards the sensory characteristics assessed in raspberry, comparison of the samples subjected to the complete process with fresh controls revealed significant differences in terms of sweet taste ( $\mathrm{LSD}=0.36)$, bitter taste $(\mathrm{LSD}=0.39)$, redness ( $\mathrm{LSD}=0.33$ ) and shine ( $L S D=0.32$ ). However, panellists detected no significant differences between sensory texture parameters for the different samples. The pre-treatment prior to freezing appears to have 
masked the true effects of the freezing and thawing rates on tissue structure. As for the effect of freezing and thawing rates, in the case of blackberry panellists found no significant differences between sensory characteristics assessed in fresh and processed fruits, showing that in spite of the differences indicated by other parameters, these were not sufficiently great to be detected by sensory analysis. Table 5 also includes correlations established for both fruits between objective and sensory characteristics of texture. In the case of raspberry, none of the correlations was significant. Firmness presented the highest positive correlation with back extrusion energy ( $r=0.638$ ), and juiciness the highest negative correlation with multiple penetration maximum force $(r=-0.599)$. Other study showed that sensory firmness gave the highest correlation with back extrusion maximum force in raspberry stored during 12 months [25]. In the case of blackberry, firmness presented a significant positive correlation with back extrusion and compression maximum forces ( $r=0.794$ and $r=0.842$ respectively).

\section{Conclusions}

For both fruits, pre-treatments with $\mathrm{CaCl}_{2}$ and low methyl pectin (LMP), applied either separately or in combined solutions, produced a statistically significant effect on the structure of the fruits, such that tissue mechanical strength augmented with increasing concentrations. When no further processing was applied, the values of the objective texture parameters were highest after a pre-treatment with $\mathrm{CaCl}_{2}(100 \mathrm{mM})$ in both fruits. Multiple penetration

maximum force $\left(F_{\mathrm{MP}}\right)$ may be the most expressive parameter for assessing the firmness of both fresh and pre-treated fruits without further processing, having the added advantage of being independent of sample weight. As regards freezing and thawing rates, the results show that freezing by forced convection with liquid nitrogen vapour at $-40{ }^{\circ} \mathrm{C}\left(R_{\mathrm{f}}=3.3{ }^{\circ} \mathrm{C} \min ^{-1}\right.$ for 
raspberry and $R_{\mathrm{f}}=2.2{ }^{\circ} \mathrm{C} \mathrm{min}^{-1}$ for blackberry respectively) resulted in better preservation of both structures as compared to fresh controls. Raspberry fruits should be thawed slowly at 5 ${ }^{\circ} \mathrm{C}\left(R_{\mathrm{t}}=0.05{ }^{\circ} \mathrm{C} \mathrm{min}^{-1}\right)$, whereas blackberry fruits may be thawed quickly at room temperature $\left(R_{\mathrm{t}}=0.12{ }^{\circ} \mathrm{C} \min ^{-1}\right)$ without suffering excessive cell damage. Sensory characteristics and microphotographs corroborated the results of mechanical tests. With respect to the complete freezing process, the results showed that calcium was more effective than low methyl pectin as a protective pre-treatment for preventing freezing-induced loss of firmness in both fruits. A pre-treatment with $\mathrm{CaCl}_{2}(100 \mathrm{mM})$, applied independently or combined with LMP, should be applied in both fruits prior to freezing; freezing rates should be no higher than those attained by forced convection with liquid nitrogen vapour at $-40{ }^{\circ} \mathrm{C}$. Multiple penetration was the test that best reflected the changes occurring in the turgidity of raspberry as a result of freezing. In the case of both fresh and frozen blackberries, the slope derived from the compression test was the parameter that best expressed the firmness of the product. 
Acknowledgements The authors wish to thank the Instituto Nacional de Investigação Agrária (INIA Proj Piddac 117/97), the Consejo Superior Investigaciones Científicas (CICyT, Project ALI98-1055) (Spain) and Junta Nacional de Investigacão Científica y Tecnológica de Portugal (Proc n 423/CSIC), which financially supported this cooperative research. 


\section{References}

1. Lin T-T, Pitt RE (1986) J Texture Stud 17:291-313

2. Brusewitz GH, Pitt RE, Gao Q (1989) J Texture Stud 20:267-284

3. Ramana SV, Taylor AJ (1994) J Food Sci Technol Ind 31:236-237

4. Alvarez MD, Saunders DEJ, Vincent JFV (2000) Eur Food Res Technol 210:331-339

5. Alonso J, Canet W, Rodríguez T (1994) J Sci Food Agric 66:1-7

6. Alonso J, Rodríguez, Canet,W (1995) J Agric Food Chem 43:1011-1016

7. Alonso J, Canet W, Rodríguez T (1997) J Food Sci 62:11-515

8. Grout BWW, Morris GJ, McLellan MR (1989) The freezing of fruit and vegetables. In: Bald WB (ed) Food freezing: today and tomorrow. Springer Series in Applied Biology, London, pp 113-122

9. Reid DS (1993) Basic physical phenomena in the freezing and thawing of plant and animal tissues. In Mallett CP (ed) Frozen, food technology, Chap 1. Blackie Academic \& Professional , Glasgow, pp 1-19

10. Alvarez MD, Canet W (1997) Z Lebensm Unters Forsch A 196:282-289

11. Martí J, Aguilera JM (1991) Rev Agroquim Tecnol Alim 31:493-504

12. Crivelli G, Senesi E (1990) Frutticoltura 52:11-16

13. Reynoso RO, Michelis A (1994) Rev Int Froid 17:209-213

14. Delgado AE, Rubiolo AC (2005) Lebensm Wiss Technol 38:135-142

15. Canet W, Hill M (1987) Int J Food Sci 22:273-277

16. Fuchigami M, Miyazaki K, Hyakumoto N (1995) J Food Sci 60:132-136

17. McFeeters RF, Fleming HP (1989) J Agric Food Chem 37:1053-1059

18. Alonso J, Canet W, Rodríguez MT (1993) Z Lebensm Unters Forsch A 196:214-218

19. Alvarez MD, Canet W, Tortosa ME (1997) Z Lebensm Unters Forsch A 204:356-364

20. Santerre CR, Cash JN, Iezzoni AF (1991) J Food Sci 56:260-261 
21. Jadhav SJ, Mazza G, Desai, UT (1991) Postharvest handling and storage In: Salunkhe DK, Kadam SS, Jadhav SJ (eds) Potato: production, processing, and products, Chapt 4. CRC Press, Boca Ratón, FL, pp 69109

22. Bourne MC (1982) J Food Sci 47:440-444

23. Institut International du Froid (1986) Recommendations pour la Préparation et la Distribuition des Aliments Congelés, Ceuterick S.A, Belgium, $3^{\circ}$ edn

24. Sousa MB, Abano R, Mota T, Canet W (1995) Reologia y textura de productos alimentarios de interés industrial. In: Gallegos C, Guerrero A, Muñoz (eds) Evaluación objectiva de la textura de frambuesa (cv. Heritage). Efecto de tratamientos protectores y las velocidades de congelación y descongelación. Real Sociedad Española de Quimica, Sevilla, pp 39-49

25. Sousa MB, Canet W, Alvarez MD, Tortosa ME (2005) Eur Food Res Technol, DOI 10.1007/s00217-0051189-1

26. Canet W (1988) J Microwave Power 23:231-235

27. Canet W, Tortosa ME (1990) In: Sociedad Española de Ciencias Hortícolas (ed) Estudio de las modificaciones estructurales y de textura debidas a la congelación de guisante. Actas de Horticultura. Córdoba, Sociedad Española de Ciencias Hortícolas, Córdoba, pp 480-485

28. Stanley R (1988) The suitability of soft fruit varieties for processing. 1987 Trials. Technical memorandum, 494. The Campden Food Preservation Research Association, Chipping, Campden

29. Hudson JM, Buescher RW (1975) J Food Sci 51:138-140, 149

30. Marchiner H (1986) Mineral nutrition of higher plants In Javanovich HB (ed), Academic Press Inc, London

31. Partmann W (1975) The effects of freezing and thawing on food quality In: Duckworth RB (ed) Water relations of foods, Academic Press Inc, London, pp 505-537

32. Brown MH (1991) Microbiological aspects of frozen foods In Bald WD (ed) Food freezing: today and tomorrow, Springer, London, pp 15-25 


\section{Captions}

Fig. 1 Microphotographs corresponding to fresh raspberry epidermis tissues (cv. Heritage). 1 Fresh raspberry $(1 \mathrm{~cm}=625 \mu \mathrm{m}) .2$ Fresh raspberry $(1 \mathrm{~cm}=72.5 \mu \mathrm{m}) .3$ Fresh raspberry $(1 \mathrm{~cm}=14.5 \mu \mathrm{m})$

Fig. 2 Microphotographs corresponding to fresh blackberry epidermis tissues (cv. Thornfree). 1 Fresh blackberry $(1 \mathrm{~cm}=43.5 \mu \mathrm{m}) .2$ Fresh blackberry $(1 \mathrm{~cm}=21.7 \mu \mathrm{m})$

Fig. 3 Microphotographs corresponding to fresh raspberry epidermis tissues (cv. Heritage). 1 Treated in $\mathrm{CaCl}_{2}$, $100 \mathrm{mM}$ raspberry $(1 \mathrm{~cm}=625 \mu \mathrm{m}) .2$ Treated in $\mathrm{CaCl}_{2}, 100 \mathrm{mM}$ raspberry $(1 \mathrm{~cm}=109 \mu \mathrm{m})$

Fig. 4 Microphotographs corresponding to fresh blackberry epidermis tissues (cv. Thornfree). 1 Treated in $\mathrm{CaCl}_{2}, 100 \mathrm{mM}$ and LMP, 3\% blackberry $(1 \mathrm{~cm}=8.33 \mu \mathrm{m}) .2$ Treated in $\mathrm{CaCl}_{2}, 100 \mathrm{mM}$ and $\mathrm{LMP}, 3 \%$ blackberry $(1 \mathrm{~cm}=33.3 \mu \mathrm{m})$

Fig. 5 a-h Effect of freezing and thawing rates on textural parameters of raspberry. a Kramer shear maximum force, $\mathbf{b}$ back extrusion maximum force, $\mathbf{c}$ compression maximum force, $\mathbf{d}$ multiple penetration maximum force, e Kramer shear energy, f back extrusion energy; $\mathbf{g}$ compression slope, $\mathbf{h}$ multiple penetration slope. ${ }^{* *}, * * *$ significant levels at $1 \%, 0.1 \%$ respectively; NS: not significant

Fig. 6 a-h Effect of freezing and thawing rates on textural parameters of blackberry. a Kramer shear maximum force, $\mathbf{b}$ back extrusion maximum force, $\mathbf{c}$ compression maximum force, $\mathbf{d}$ multiple penetration maximum force,

e Kramer shear energy, f back extrusion energy; $\mathbf{g}$ compression slope, $\mathbf{h}$ multiple penetration slope. ${ }^{* * * * * * *}$ significant levels at $5 \%, 1 \%, 0.1 \%$ respectively; NS: not significant

Fig. 7 Microphotographs corresponding to raspberry epidermis tissues (cv. Heritage) at different freezing/thawing specifications. 1 Fresh control. 2 Frozen at $309{ }^{\circ} \mathrm{C} \mathrm{min}{ }^{-1}$ and thawed at $0.18{ }^{\circ} \mathrm{C} \mathrm{min}{ }^{-1}$ tissue. 3 Frozen at $309{ }^{\circ} \mathrm{C} \min ^{-1}$ and thawed at $0.05{ }^{\circ} \mathrm{C} \mathrm{min}{ }^{-1}$ tissue. 4 Frozen at $3.3{ }^{\circ} \mathrm{C} \mathrm{min}^{-1}$ and thawed at $0.18{ }^{\circ} \mathrm{C} \mathrm{min}{ }^{-1}$ tissue. 5 Frozen at $3.3^{\circ} \mathrm{C} \min ^{-1}$ and thawed at $0.05{ }^{\circ} \mathrm{C} \min ^{-1}$ tissue. $(1 \mathrm{~cm}=72.5 \mu \mathrm{m})$

Fig. 8 Microphotographs corresponding to blackberry epidermis tissues (cv. Thornfree) at different freezing/thawing specifications. 1 Fresh control. 2 Frozen at $140{ }^{\circ} \mathrm{C} \mathrm{min}{ }^{-1}$ and thawed at $0.12{ }^{\circ} \mathrm{C} \mathrm{min}{ }^{-1}$ tissue. 3 Frozen at $140{ }^{\circ} \mathrm{C} \min ^{-1}$ and thawed at $0.04{ }^{\circ} \mathrm{C} \mathrm{min}{ }^{-1}$ tissue. 4 Frozen at $2.2{ }^{\circ} \mathrm{C} \mathrm{min}^{-1}$ and thawed at $0.12{ }^{\circ} \mathrm{C} \mathrm{min}{ }^{-1}$ tissue. 5 Frozen at $2.2{ }^{\circ} \mathrm{C} \mathrm{min}^{-1}$ and thawed at $0.04{ }^{\circ} \mathrm{C} \min ^{-1}$ tissue. $(1 \mathrm{~cm}=33.3 \mu \mathrm{m})$ 
Fig. 9 Microphotographs corresponding to raspberry epidermis tissues (cv. Heritage) subjected to complete freezing process without and with pre-treatments. 1 Fresh control. 2 Frozen at $3.3{ }^{\circ} \mathrm{C} \mathrm{min}^{-1}$ and thawed at $0.05{ }^{\circ} \mathrm{C}$ $\min ^{-1}$ tissue. 3 Treated in $\mathrm{CaCl}_{2}, 100 \mathrm{mM}$ and frozen at $3.3{ }^{\circ} \mathrm{C} \mathrm{min}^{-1}$ and thawed at $0.0{ }^{\circ} \mathrm{C} \mathrm{min}^{-1}$ tissue. 4 Treated in $\mathrm{CaCl}_{2}, 100 \mathrm{mM}$ and $\mathrm{LMP}, 0.1 \%$ and frozen at $3.3{ }^{\circ} \mathrm{C} \mathrm{min}^{-1}$ and thawed at $0.05^{\circ} \mathrm{C} \mathrm{min}^{-1}$ tissue. $(1 \mathrm{~cm}=72.5 \mu \mathrm{m})$ Fig. 10 Microphotographs corresponding to blackberry epidermis tissues (cv. Thornfree) subjected to complete freezing process without and with pre-treatments. 1 Fresh control. 2 Frozen at $2.2{ }^{\circ} \mathrm{C} \min ^{-1}$ and thawed at $0.12{ }^{\circ} \mathrm{C}$ $\min ^{-1}$ tissue. 3 Treated in $\mathrm{CaCl}_{2}, 100 \mathrm{mM}$ and frozen at $2.2{ }^{\circ} \mathrm{C} \mathrm{min}^{-1}$ and thawed at $0.12{ }^{\circ} \mathrm{C} \mathrm{min}^{-1}$ tissue. 4 Treated in LMP, $2 \%$ and frozen at $2.2{ }^{\circ} \mathrm{C} \mathrm{min}^{-1}$ and thawed at $0.12{ }^{\circ} \mathrm{C} \mathrm{min}^{-1}$ tissue. 5 Treated in $\mathrm{CaCl}_{2}, 100 \mathrm{mM}$ and LMP, $1 \%$ and frozen at $2.2^{\circ} \mathrm{C} \mathrm{min}^{-1}$ and thawed at $0.12{ }^{\circ} \mathrm{C} \mathrm{min}^{-1}$ tissue. 6 Treated in $\mathrm{CaCl}_{2}, 100 \mathrm{mM}$ and $\mathrm{LMP}$, $3 \%$ and frozen at $2.2{ }^{\circ} \mathrm{C} \min ^{-1}$ and thawed at $0.12{ }^{\circ} \mathrm{C} \quad \min ^{-1}$ tissue. $(1 \mathrm{~cm}=72.5 \mu \mathrm{m})$ 

Table 1 Effect of calcium pre-treatments on texture parameters ${ }^{\mathrm{a}}$ of raspberry (cv. Heritage) and blackberry (cv. Thornfree)

\begin{tabular}{|c|c|c|c|c|c|c|c|c|}
\hline $\begin{array}{l}\text { Protective Pre-treatment } \\
{\left[\mathrm{CaCl}_{2}\right]}\end{array}$ & $\begin{array}{l}F_{\mathrm{KSC}} \\
(\mathrm{N})\end{array}$ & $\begin{array}{l}E_{\mathrm{KSC}} \\
\left(\mathrm{J} 10^{-2}\right)\end{array}$ & $\begin{array}{l}F_{\mathrm{E}} \\
(\mathrm{N})\end{array}$ & $\begin{array}{l}E_{\mathrm{E}} \\
\left(\mathrm{J} 10^{-2}\right)\end{array}$ & $\begin{array}{l}F_{\mathrm{C}} \\
(\mathrm{N})\end{array}$ & $\begin{array}{l}S_{\mathrm{C}} \\
\left(\mathrm{N} \mathrm{mm}^{-1}\right)\end{array}$ & $\begin{array}{l}F_{\mathrm{MP}} \\
(\mathrm{N})\end{array}$ & $\begin{array}{l}S_{\mathrm{MP}} \\
\left(\mathrm{N} \mathrm{mm}^{-1}\right)\end{array}$ \\
\hline \multicolumn{9}{|l|}{ Raspberry } \\
\hline $1 \mathrm{mM}$ & $6.62^{\mathrm{ab}}$ & 6.02 & $16.72^{\mathrm{b}}$ & 6.43 & 32.26 & $8.57^{\mathrm{a}}$ & $6.54^{\mathrm{ab}}$ & $6.55^{\mathrm{ab}}$ \\
\hline $10 \mathrm{mM}$ & $6.78^{\mathrm{a}}$ & 6.29 & $17.86^{\mathrm{b}}$ & 6.66 & 35.08 & $9.30^{\mathrm{ab}}$ & $6.54^{\mathrm{ab}}$ & $6.94^{\mathrm{a}}$ \\
\hline $100 \mathrm{mM}$ & $6.81^{\mathrm{a}}$ & 6.41 & $20.83^{\mathrm{a}}$ & 7.49 & 34.74 & $10.69^{\mathrm{a}}$ & $6.88^{\mathrm{a}}$ & $7.62^{c}$ \\
\hline Fresh control & $6.33^{\mathrm{b}}$ & 6.03 & $20.08^{\mathrm{a}}$ & 6.57 & 34.65 & $8.67^{\mathrm{b}}$ & $6.19^{\mathrm{b}}$ & $6.37^{\mathrm{b}}$ \\
\hline Significant level & $* *$ & NS & $* * *$ & NS & NS & $* *$ & $* *$ & $* *$ \\
\hline LSD, $99 \%$ & 0.39 & - & 1.46 & - & - & 1.62 & 0.49 & 0.42 \\
\hline \multicolumn{9}{|l|}{ Blackberry } \\
\hline $1 \mathrm{mM}$ & $19.51^{\mathrm{ab}}$ & $24.00^{\mathrm{a}}$ & $21.13^{\mathrm{a}}$ & $16.30^{\mathrm{a}}$ & $31.66^{\mathrm{a}}$ & $7.19^{\mathrm{ab}}$ & $5.63^{\mathrm{a}}$ & $8.82^{\mathrm{a}}$ \\
\hline $10 \mathrm{mM}$ & $20.23^{\mathrm{a}}$ & $35.00^{\mathrm{b}}$ & $21.57^{\mathrm{a}}$ & $18.00^{\mathrm{a}}$ & $37.93^{b}$ & $8.19^{b}$ & $7.10^{\mathrm{b}}$ & $9.77^{\mathrm{b}}$ \\
\hline $100 \mathrm{mM}$ & $25.53^{\mathrm{c}}$ & $41.20^{\mathrm{c}}$ & $27.56^{\mathrm{b}}$ & $28.00^{\mathrm{b}}$ & $39.13^{b c}$ & $9.43^{\mathrm{bc}}$ & $7.09^{\mathrm{b}}$ & $10.17^{\mathrm{bc}}$ \\
\hline Fresh control & $16.22^{\mathrm{b}}$ & $20.40^{\mathrm{d}}$ & $19.88^{\mathrm{a}}$ & $16.50^{\mathrm{a}}$ & $27.66^{\mathrm{a}}$ & $6.55^{\mathrm{a}}$ & $5.33^{\mathrm{a}}$ & $8.52^{\mathrm{a}}$ \\
\hline Significant level & $* * *$ & $* * *$ & $* * *$ & $* * *$ & $* * *$ & $* * *$ & $* * *$ & $*$ \\
\hline LSD, $99 \%$ & 3.71 & 5.10 & 2.11 & 2.40 & 4.99 & 1.41 & 0.72 & 0.70 \\
\hline
\end{tabular}

${ }^{\mathrm{a}} F_{\mathrm{KSC}}$ Kramer shear maximum force, $E_{\mathrm{KSC}}$ Kramer shear energy, $F_{\mathrm{E}}$ back extrusion maximum force, $E_{\mathrm{E}}$ back extrusion energy,

$F_{\mathrm{C}}$ compression maximum force, $S_{\mathrm{C}}$ compression slope, $F_{\mathrm{MP}}$ multiple penetration maximum force, $S_{\mathrm{MP}}$ multiple penetration slope.

Different letters in the same column indicate significant differences; ${ }^{* * * * * * * *}$ significant levels at $5 \%, 1 \%, 0.1 \%$ respectively;

NS: not significant 
Table 2 Effect of low methoxyl pectin (LMP) pre-treatments on texture parameters ${ }^{\mathrm{a}}$ of raspberry (cv. Heritage) and blackberry (cv. Thornfree)

\begin{tabular}{lllllllll}
\hline $\begin{array}{l}\text { Protective Pre-treatment } \\
{[\mathrm{LMP}]}\end{array}$ & $\begin{array}{l}F_{\mathrm{KSC}} \\
(\mathrm{N})\end{array}$ & $\begin{array}{l}E_{\mathrm{KSC}} \\
\left(\mathrm{J} 10^{-2}\right)\end{array}$ & $\begin{array}{l}F_{\mathrm{E}} \\
(\mathrm{N})\end{array}$ & $\begin{array}{l}E_{\mathrm{E}} \\
\left(\mathrm{J} 10^{-2}\right)\end{array}$ & $\begin{array}{l}F_{\mathrm{C}} \\
(\mathrm{N})\end{array}$ & $\begin{array}{l}S_{\mathrm{C}} \\
\left(\mathrm{N} \mathrm{mm}^{-1}\right)\end{array}$ & $\begin{array}{l}F_{\mathrm{MP}} \\
(\mathrm{N})\end{array}$ & $\begin{array}{l}S_{\mathrm{MP}} \\
(\mathrm{N} \mathrm{mm})\end{array}$ \\
\hline $\begin{array}{l}\text { Raspberry } \\
0.1 \%\end{array}$ & 6.46 & 5.73 & $15.07^{\mathrm{c}}$ & $5.39^{\mathrm{b}}$ & $35.26^{\mathrm{b}}$ & $9.18^{\mathrm{b}}$ & $6.07^{\mathrm{b}}$ & $6.53^{\mathrm{bc}}$ \\
$0.2 \%$ & 6.31 & 5.79 & $15.22^{\mathrm{c}}$ & $5.44^{\mathrm{b}}$ & $31.84^{\mathrm{b}}$ & $9.33^{\mathrm{b}}$ & $6.23^{\mathrm{b}}$ & $7.79^{\mathrm{ab}}$ \\
$0.3 \%$ & 6.23 & 6.14 & $16.88^{\mathrm{b}}$ & $5.36^{\mathrm{b}}$ & $38.95^{\mathrm{a}}$ & $11.57^{\mathrm{a}}$ & $6.93^{\mathrm{a}}$ & $7.86^{\mathrm{a}}$ \\
Fresh control & 6.33 & 6.03 & $20.08^{\mathrm{a}}$ & $6.57^{\mathrm{a}}$ & $34.65^{\mathrm{b}}$ & $8.67^{\mathrm{b}}$ & $6.19^{\mathrm{b}}$ & $6.37^{\mathrm{c}}$ \\
Significant level & $\mathrm{NS}$ & $\mathrm{NS}$ & $* * *$ & $* * *$ & $* *$ & $* * *$ & $* * *$ & $* *$ \\
LSD, 99\% & - & - & 1.41 & 0.67 & 4.29 & 1.46 & 0.39 & 1.37 \\
Blackberry & & & & & & & & \\
$1 \%$ & $19.60^{\mathrm{a}}$ & $24.60^{\mathrm{a}}$ & $19.99^{\mathrm{a}}$ & $15.10^{\mathrm{a}}$ & $20.65^{\mathrm{a}}$ & $7.19^{\mathrm{ab}}$ & $5.96^{\mathrm{a}}$ & $8.73^{\mathrm{a}}$ \\
$2 \%$ & $21.11^{\mathrm{ab}}$ & $30.20^{\mathrm{b}}$ & $20.98^{\mathrm{a}}$ & $16.50^{\mathrm{b}}$ & $31.42^{\mathrm{b}}$ & $8.19^{\mathrm{b}}$ & $6.16^{\mathrm{a}}$ & $9.89^{\mathrm{b}}$ \\
$3 \%$ & $21.51^{\mathrm{b}}$ & $31.20^{\mathrm{c}}$ & $25.74^{\mathrm{b}}$ & $24.40^{\mathrm{c}}$ & $37.74^{\mathrm{c}}$ & $9.43^{\mathrm{bc}}$ & $7.74^{\mathrm{b}}$ & $10.43^{\mathrm{bc}}$ \\
Fresh control & $16.22^{\mathrm{c}}$ & $20.40^{\mathrm{d}}$ & $19.88^{\mathrm{a}}$ & $16.50^{\mathrm{b}}$ & $27.66^{\mathrm{d}}$ & $6.55^{\mathrm{a}}$ & $5.33^{\mathrm{a}}$ & $8.52^{\mathrm{a}}$ \\
Significant level & $* * *$ & $* * *$ & $* * *$ & $* * *$ & $* * *$ & $* * *$ & $* * *$ & $*$ \\
LSD, 99\% & 1.53 & 0.59 & 3.31 & 0.35 & 3.62 & 1.41 & 0.94 & 0.90 \\
\hline
\end{tabular}

${ }^{\mathrm{a}} F_{\mathrm{KSC}}$ Kramer shear maximum force, $E_{\mathrm{KSC}}$ Kramer shear energy, $F_{\mathrm{E}}$ back extrusion maximum force, $E_{\mathrm{E}}$ back extrusion energy,

$F_{\mathrm{C}}$ compression maximum force, $S_{\mathrm{C}}$ compression slope, $F_{\mathrm{MP}}$ multiple penetration maximum force, $S_{\mathrm{MP}}$ multiple penetration slope;

Different letters in the same column indicate significant differences; ${ }^{* * * * * * *}$ significant levels at $5 \%, 1 \%, 0.1 \%$ respectively;

NS: not significant 
Table 3 Effect of combined pre-treatments on texture parameters ${ }^{\mathrm{a}}$ of raspberry (cv. Heritage) and blackberry (cv. Thornfree)

\begin{tabular}{lllllllll}
\hline Protective Pre-treatment & $F_{\mathrm{KSC}}$ & $E_{\mathrm{KSC}}$ & $F_{\mathrm{E}}$ & $E_{\mathrm{E}}$ & $F_{\mathrm{C}}$ & $S_{\mathrm{C}}$ & $F_{\mathrm{MP}}$ & $\begin{array}{l}S_{\mathrm{MP}} \\
{\left[\mathrm{CaCl}_{2}\right]+[\mathrm{LMP}]}\end{array}$ \\
\hline Raspberry & $(\mathrm{N})$ & $\left(\mathrm{J} 10^{-2}\right)$ & $(\mathrm{N})$ & $\left(\mathrm{J} 10^{-2}\right)$ & $(\mathrm{N})$ & $\left(\mathrm{N} \mathrm{mm}^{-1}\right)$ & $(\mathrm{N})$ & $(\mathrm{N} \mathrm{mm})$ \\
$1 \mathrm{mM}+0.1 \%$ & & & & & & & & \\
$100 \mathrm{mM}+0.1 \%$ & $5.92^{\mathrm{bc}}$ & $6.11^{\mathrm{b}}$ & $15.56^{\mathrm{c}}$ & $5.48^{\mathrm{c}}$ & 32.61 & $8.04^{\mathrm{ab}}$ & $6.80^{\mathrm{b}}$ & $5.47^{\mathrm{bc}}$ \\
$1 \mathrm{mM}+0.3 \%$ & $6.71^{\mathrm{a}}$ & $7.79^{\mathrm{a}}$ & $18.15^{\mathrm{b}}$ & $7.14^{\mathrm{a}}$ & 33.80 & $9.35^{\mathrm{a}}$ & $7.57^{\mathrm{a}}$ & $6.76^{\mathrm{a}}$ \\
$100 \mathrm{mM}+0.3 \%$ & $5.84^{\mathrm{c}}$ & $6.09^{\mathrm{b}}$ & $15.60^{\mathrm{c}}$ & $5.42^{\mathrm{c}}$ & 30.98 & $7.67^{\mathrm{b}}$ & $6.15^{\mathrm{c}}$ & $4.97^{\mathrm{c}}$ \\
Fresh control & $6.57^{\mathrm{a}}$ & $7.12^{\mathrm{a}}$ & $17.65^{\mathrm{bc}}$ & $6.05^{\mathrm{bc}}$ & 36.49 & $9.38^{\mathrm{a}}$ & $6.30^{\mathrm{c}}$ & $5.93^{\mathrm{abc}}$ \\
Significant level & $6.33^{\mathrm{ab}}$ & $6.03^{\mathrm{b}}$ & $20.08^{\mathrm{a}}$ & $6.57^{\mathrm{ab}}$ & 34.65 & $8.67^{\mathrm{ab}}$ & $6.19^{\mathrm{c}}$ & $6.37^{\mathrm{ab}}$ \\
LSD, 99\% & $* * *$ & $* * *$ & $* * *$ & $* * *$ & $\mathrm{NS}$ & $* *$ & $* * *$ & $* * *$ \\
Blackberry & 0.46 & 0.73 & 1.95 & 0.71 & - & 1.37 & 0.42 & 0.97 \\
$10 \mathrm{mM}+1 \%$ & & & & & & & & \\
$100 \mathrm{mM}+1 \%$ & $14.09^{\mathrm{bc}}$ & $20.30^{\mathrm{a}}$ & $15.12^{\mathrm{c}}$ & $14.90^{\mathrm{a}}$ & $22.17^{\mathrm{a}}$ & 5.15 & $4.43^{\mathrm{a}}$ & $7.38^{\mathrm{b}}$ \\
$10 \mathrm{mM}+3 \%$ & $15.95^{\mathrm{a}}$ & $22.50^{\mathrm{b}}$ & $20.82^{\mathrm{b}}$ & $18.80^{\mathrm{b}}$ & $23.18^{\mathrm{a}}$ & 5.95 & $5.71^{\mathrm{b}}$ & $9.29^{\mathrm{a}}$ \\
$100 \mathrm{mM}+3 \%$ & $14.40^{\mathrm{c}}$ & $31.10^{\mathrm{c}}$ & $15.17^{\mathrm{c}}$ & $15.80^{\mathrm{c}}$ & $23.69^{\mathrm{a}}$ & 5.17 & $5.04^{\mathrm{c}}$ & $7.56^{\mathrm{b}}$ \\
Fresh control & $16.71^{\mathrm{a}}$ & $26.10^{\mathrm{d}}$ & $25.09^{\mathrm{a}}$ & $20.90^{\mathrm{d}}$ & $25.71^{\mathrm{b}}$ & 6.03 & $6.04^{\mathrm{b}}$ & $9.11^{\mathrm{a}}$ \\
Significant level & $12.97^{\mathrm{b}}$ & $13.50^{\mathrm{e}}$ & $15.90^{\mathrm{c}}$ & $13.50^{\mathrm{e}}$ & $22.09^{\mathrm{a}}$ & 5.16 & $3.41^{\mathrm{d}}$ & $6.82^{\mathrm{b}}$ \\
LSD, 99\% & $* * *$ & $* * *$ & $* * *$ & $* * *$ & $*$ & $\mathrm{NS}$ & $* * *$ & $* * *$ \\
\hline
\end{tabular}

${ }^{a} F_{\mathrm{KSC}}$ Kramer shear maximum force, $E_{\mathrm{KSC}}$ Kramer shear energy, $F_{\mathrm{E}}$ back extrusion maximum force, $E_{\mathrm{E}}$ back extrusion energy,

$F_{\mathrm{C}}$ compression maximum force, $S_{\mathrm{C}}$ compression slope, $F_{\mathrm{MP}}$ multiple penetration maximum force, $S_{\mathrm{MP}}$ multiple penetration slope

Different letters in the same column indicate significant differences; ${ }^{* * * * * *}$ significant levels at 5\%, $1 \%, 0.1 \%$ respectively;

NS: not significant 
Table 4 Effect of complete process on texture parameters ${ }^{\mathrm{a}}$ of raspberry (cv. Heritage) and blackberry (cv. Thornfree)

\section{Complete process}

$\begin{array}{lll}F_{\mathrm{KSC}} & E_{\mathrm{KSC}} & F_{\mathrm{E}} \\ (\mathrm{N}) & \left(\mathrm{J} 10^{-2}\right) & (\mathrm{N})\end{array}$

$E_{\mathrm{E}} \quad F_{\mathrm{C}}$

$F_{\mathrm{C}}$
$(\mathrm{N})$

$S_{\mathrm{C}}$

$F_{\mathrm{MP}}$

$S_{\mathrm{MP}}$

)

$\left.{ }^{1}\right)$

\section{Raspberry}

$\mathrm{CaCl}_{2}, 1 \mathrm{mM}+$ freezing $\left(-3.3{ }^{\circ} \mathrm{C} \min ^{-1}\right)+$ thawing $\left(+0.05{ }^{\circ} \mathrm{C} \mathrm{min}^{-1}\right)$

$\mathrm{CaCl}_{2}, 100 \mathrm{mM}+$ freezing $\left(-3.3^{\circ} \mathrm{C} \mathrm{min}^{-1}\right)+$ thawing $\left(+0.05^{\circ} \mathrm{C} \mathrm{min}^{-1}\right)$

LMP, $0.1 \%+$ freezing $\left(-3.3{ }^{\circ} \mathrm{C} \mathrm{min}^{-1}\right)+$ thawing $\left(+0.05^{\circ} \mathrm{C} \mathrm{min}^{-1}\right)$

LMP, $0.3 \%+$ freezing $\left(-3.3{ }^{\circ} \mathrm{C} \min ^{-1}\right)+$ thawing $\left(+0.05^{\circ} \mathrm{C} \mathrm{min}^{-1}\right)$

6.74

$3.49^{\mathrm{b}} \quad 5.58^{\mathrm{d}}$

$7.32^{\mathrm{b}}-4.66^{\mathrm{a}}-9.15^{\mathrm{a}}$

$6.84^{\mathrm{bc}} \quad 3.74^{\mathrm{b}} \quad 6.38^{\mathrm{c}}$

$7.83^{\mathrm{a}} \quad 4.61^{\mathrm{a}} \quad 7.66^{\mathrm{b}}$

$8.16^{\mathrm{a}} \quad 5.04^{\mathrm{a}} \quad 7.97^{\mathrm{b}}$

$\mathrm{CaCl}_{2}, 100 \mathrm{mM}+\mathrm{LMP}, 0.1 \%+$ freezing $\left(-3.3{ }^{\circ} \mathrm{C} \mathrm{min}^{-1}\right)+$ thawing $\left(+0.05^{\circ} \mathrm{C} \mathrm{min}^{-1}\right)$

$\mathrm{CaCl}_{2}, 100 \mathrm{mM}+\mathrm{LMP}, 0.3 \%+$ freezing $\left(-3.3{ }^{\circ} \mathrm{C} \mathrm{min}^{-1}\right)+$ thawing $\left(+0.05^{\circ} \mathrm{C} \mathrm{min}^{-1}\right)$

Control ${ }^{1}$ : fresh material + freezing $\left(-3.3^{\circ} \mathrm{C} \mathrm{min}^{-1}\right)+$ thawing $\left(+0.05^{\circ} \mathrm{C} \mathrm{min}{ }^{-1}\right)$

$\mathrm{Control}^{2}$ : fresh material with sugar + freezing $\left(-3.3{ }^{\circ} \mathrm{C} \mathrm{min}^{-1}\right)+$ thawing $\left(+0.05{ }^{\circ} \mathrm{C} \mathrm{min}{ }^{-1}\right)$ Significant level

LSD, 99\%

Blackberry

$\mathrm{CaCl}_{2}, 10 \mathrm{mM}+$ freezing $\left(-2.2^{\circ} \mathrm{C} \mathrm{min}^{-1}\right)+$ thawing $\left(+0.12{ }^{\circ} \mathrm{C} \mathrm{min}^{-1}\right)$

$\mathrm{CaCl}_{2}, 100 \mathrm{mM}+$ freezing $\left(-2.2^{\circ} \mathrm{C} \mathrm{min}^{-1}\right)+$ thawing $\left(+0.12^{\circ} \mathrm{C} \mathrm{min}^{-1}\right)$

LMP, $1 \%+$ freezing $\left(-2.2{ }^{\circ} \mathrm{C} \mathrm{min}^{-1}\right)+$ thawing $\left(+0.12{ }^{\circ} \mathrm{C} \mathrm{min}^{-1}\right)$

LMP, $3 \%+$ freezing $\left(-2.2{ }^{\circ} \mathrm{C} \mathrm{min}^{-1}\right)+$ thawing $\left(+0.12{ }^{\circ} \mathrm{C} \mathrm{min}^{-1}\right)$

$\mathrm{CaCl}_{2}, 100 \mathrm{mM}+\mathrm{LMP}, 1 \%+$ freezing $\left(-2.2^{\circ} \mathrm{C} \mathrm{min}^{-1}\right)+$ thawing $\left(+0.12{ }^{\circ} \mathrm{C} \mathrm{min}^{-1}\right)$

$\mathrm{CaCl}_{2}, 100 \mathrm{mM}+\mathrm{LMP}, 3 \%+$ freezing $\left(-2 .{ }^{\circ} \mathrm{C} \mathrm{min}^{-1}\right)+$ thawing $\left(+0.12{ }^{\circ} \mathrm{C} \mathrm{min}^{-1}\right)$

Control ${ }^{1}$ : fresh material + freezing $\left(-2.2{ }^{\circ} \mathrm{C} \mathrm{min}^{-1}\right)+$ thawing $\left(+0.12{ }^{\circ} \mathrm{C} \min ^{-1}\right)$

Significante level

$7.86^{\mathrm{a}}$

$6.77^{\mathrm{c}} \quad 3.62^{\mathrm{b}}$

$\begin{array}{ll}6.99^{\mathrm{bc}} & 3.62^{\mathrm{b}}\end{array}$

$* * * \quad * * *$

0.48

0.60

$20.56^{\mathrm{abc}} \quad 3.12^{\mathrm{abc}}$

$21.44^{\mathrm{a}} \quad 3.43^{\mathrm{a}}$

$20.14^{\text {bc }} \quad 2.87^{\text {cd }}$

$21.06^{\mathrm{ab}} \quad 3.02^{\mathrm{bc}}$

$19.77^{\mathrm{c}} \quad 3.30^{\mathrm{ab}}$

$20.20^{\mathrm{bc}} \quad 3.22^{\mathrm{abc}}$

$16.02^{\mathrm{d}} \quad 2.51^{\mathrm{d}}$

$* * * \quad * *$

0.94

0.37

$7.48^{\mathrm{b}}$
$6.66^{\mathrm{c}}$

$5.44^{\mathrm{d}}$

$* * *$

0.69

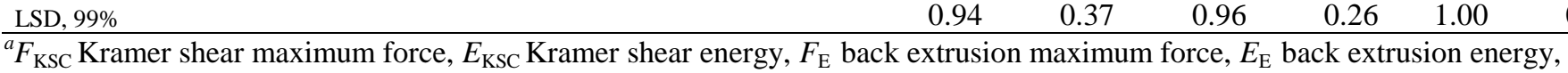

$2.50^{\mathrm{d}} \quad 6.89^{\mathrm{f}} \quad 1.73^{\mathrm{c}}$

$3.70^{\mathrm{a}} \quad 8.10^{\mathrm{bcd}} \quad 2.43^{\mathrm{a}}$

$2.81^{\mathrm{cd}} 7.06^{\mathrm{ef}}$

$3.37^{\mathrm{ab}} \quad 8.88^{\mathrm{ab}}$

$3.59^{\mathrm{a}} \quad 9.34^{\mathrm{a}}$

$2.09^{\mathrm{b}}$

$2.36^{\mathrm{a}}$

$3.56^{\mathrm{ab}} \quad 8.52^{\mathrm{abc}}$

$3.17^{\text {bc }} \quad 7.73^{\text {cde }}$

$2.80^{\text {cd }} \quad 7.38^{\text {def }}$

*** ***

$2.19^{\mathrm{ab}}$
$1.75^{\mathrm{c}}$

$\begin{array}{ll}1.75^{\mathrm{c}} & 2.95^{\mathrm{cd}}\end{array}$

$\begin{array}{ll}1.75^{\mathrm{c}} & 3.27^{\mathrm{b}}\end{array}$

$* * *$

0.26

$* * *$

0.28

$2.87^{\text {cd }}$

$3.10^{\mathrm{bc}}$

$2.75^{\mathrm{d}}$

$3.08^{\mathrm{bc}}$

$2.23^{\mathrm{bc}}$

$2.53^{\mathrm{ab}}$

$2.10^{\mathrm{c}}$

$2.52^{\mathrm{ab}}$

$2.80^{\mathrm{a}}$

$2.70^{\mathrm{a}}$

$2.21^{\mathrm{bc}}$

$2.35^{\mathrm{bc}}$

***

0.35

$\begin{array}{llllll}23.98^{\mathrm{b}} & 2.00^{\mathrm{b}} & 21.52^{\mathrm{e}} & 3.96^{\mathrm{d}} & 10.41^{\mathrm{d}} & 11.74^{\mathrm{b}}\end{array}$

$\begin{array}{llllll}25.55^{\mathrm{a}} & 2.53^{\mathrm{a}} & 28.63^{\mathrm{a}} & 5.65^{\mathrm{a}} & 11.38^{\mathrm{b}} & 13.17^{\mathrm{a}}\end{array}$

$\begin{array}{llllll}19.93^{\mathrm{e}} & 2.05^{\mathrm{b}} & 22.82^{\mathrm{d}} & 5.09^{\mathrm{bc}} & 10.82^{\mathrm{c}} & 11.64^{\mathrm{b}}\end{array}$

$\begin{array}{llllll}21.39^{\mathrm{c}} & 2.13^{\mathrm{b}} & 24.64^{\mathrm{c}} & 5.21^{\mathrm{b}} & 11.30^{\mathrm{b}} & 11.42^{\mathrm{bc}}\end{array}$

$\begin{array}{llllll}21.02^{\text {cd }} & 2.42^{\mathrm{a}} & 24.68^{\mathrm{c}} & 5.22^{\mathrm{b}} & 10.33^{\mathrm{d}} & 10.13^{\mathrm{d}}\end{array}$

$\begin{array}{llllll}24.18^{\mathrm{b}} & 2.57^{\mathrm{a}} & 26.29^{\mathrm{b}} & 5.71^{\mathrm{a}} & 11.82^{\mathrm{a}} & 11.23^{\mathrm{c}}\end{array}$

$20.11^{\mathrm{de}} \quad 1.90^{\mathrm{b}} \quad 20.63^{\mathrm{e}} \quad 4.87^{\mathrm{c}} \quad 8.85^{\mathrm{e}} \quad 10.04^{\mathrm{d}}$

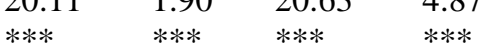

$F_{\mathrm{C}}$ compression maximum force, $S_{\mathrm{C}}$ compression slope, $F_{\mathrm{MP}}$ multiple penetration maximum force, $S_{\mathrm{MP}}$ multiple penetration slope;

a,b,c Different letters in the same column indicate significant differences; ${ }^{*, * *, * * *}$ significant levels at $5 \%, 1 \%, 0.1 \%$ respectively;

NS: not significant 
Table 5 Matrix of correlations between objective parameters from the different tests and sensory texture attributes of raspberry (cv. Heritage) and blackberry (cv. Thornfree) ${ }^{\mathrm{a}}$

\begin{tabular}{|c|c|c|c|c|c|c|c|c|c|c|}
\hline & $F_{\text {KSC }}$ & $F_{\mathrm{E}}$ & $F_{\mathrm{C}}$ & $F_{\mathrm{MP}}$ & $E_{\mathrm{KSC}}$ & $E_{\mathrm{E}}$ & $S_{\mathrm{C}}$ & $S_{\mathrm{MP}}$ & Firmness & Juiciness \\
\hline \multirow[t]{2}{*}{$F_{\mathrm{KSC}}$} & 1 & & & & & & & & & \\
\hline & 1 & & & & & & & & & \\
\hline \multirow[t]{2}{*}{$F_{\mathrm{E}}$} & 0.638 & 1 & & & & & & & & \\
\hline & 0.571 & 1 & & & & & & & & \\
\hline \multirow[t]{2}{*}{$F_{\mathrm{C}}$} & $0.946 * * *$ & 0.694 & 1 & & & & & & & \\
\hline & 0.656 & 0.644 & 1 & & & & & & & \\
\hline \multirow[t]{2}{*}{$F_{\mathrm{MP}}$} & $0.789 *$ & 0.482 & 0.708 & 1 & & & & & & \\
\hline & $0.867 *$ & 0.575 & $0.777 *$ & 1 & & & & & & \\
\hline \multirow[t]{2}{*}{$E_{\mathrm{KSC}}$} & $0.952 * * *$ & $0.810^{*}$ & $0.898^{* *}$ & $0.820^{*}$ & 1 & & & & & \\
\hline & $0.808 *$ & 0.729 & $0.810^{*}$ & 0.720 & 1 & & & & & \\
\hline \multirow{2}{*}{$E_{\mathrm{E}}$} & $0.760 *$ & $0.925 * *$ & $0.836^{*}$ & 0.708 & $0.883^{* *}$ & 1 & & & & \\
\hline & 0.513 & 0.610 & $0.909 * *$ & 0.694 & $0.832 *$ & 1 & & & & \\
\hline \multirow[t]{2}{*}{$S_{\mathrm{C}}$} & $0.796^{*}$ & $0.932 * *$ & $0.780 *$ & 0.666 & $0.923 * *$ & $0.896^{* *}$ & 1 & & & \\
\hline & 0.203 & 0.165 & $0.791 *$ & 0.534 & 0.358 & $0.757 *$ & 1 & & & \\
\hline \multirow[t]{2}{*}{$S_{\mathrm{MP}}$} & $0.944 * * *$ & 0.701 & $0.900 * *$ & $0.870^{*}$ & $0.956 * * *$ & $0.814^{*}$ & $0.884 *$ & 1 & & \\
\hline & 0.735 & 0.706 & 0.593 & 0.633 & 0.536 & 0.320 & 0.172 & 1 & & \\
\hline \multirow[t]{2}{*}{ Firmness } & 0.402 & 0.418 & 0.554 & 0.378 & 0.423 & 0.638 & 0.279 & 0.307 & 1 & \\
\hline & 0.404 & $0.794 *$ & $0.842 *$ & 0.536 & 0.607 & 0.734 & 0.618 & 0.709 & 1 & \\
\hline \multirow[t]{2}{*}{ Juiciness } & -0.182 & -0.084 & -0.057 & -0.599 & -0.276 & -0.268 & -0.086 & -0.189 & - & 1 \\
\hline & -0.306 & -0.520 & -0.396 & -0.019 & -0.695 & -0.447 & -0.050 & -0.218 & & 1 \\
\hline
\end{tabular}

${ }^{a}$ Values corresponding to blackberry are in italic

***,**** Significant correlations at $5 \%, 1 \%$, and $0.1 \%$ levels 
Figure 1
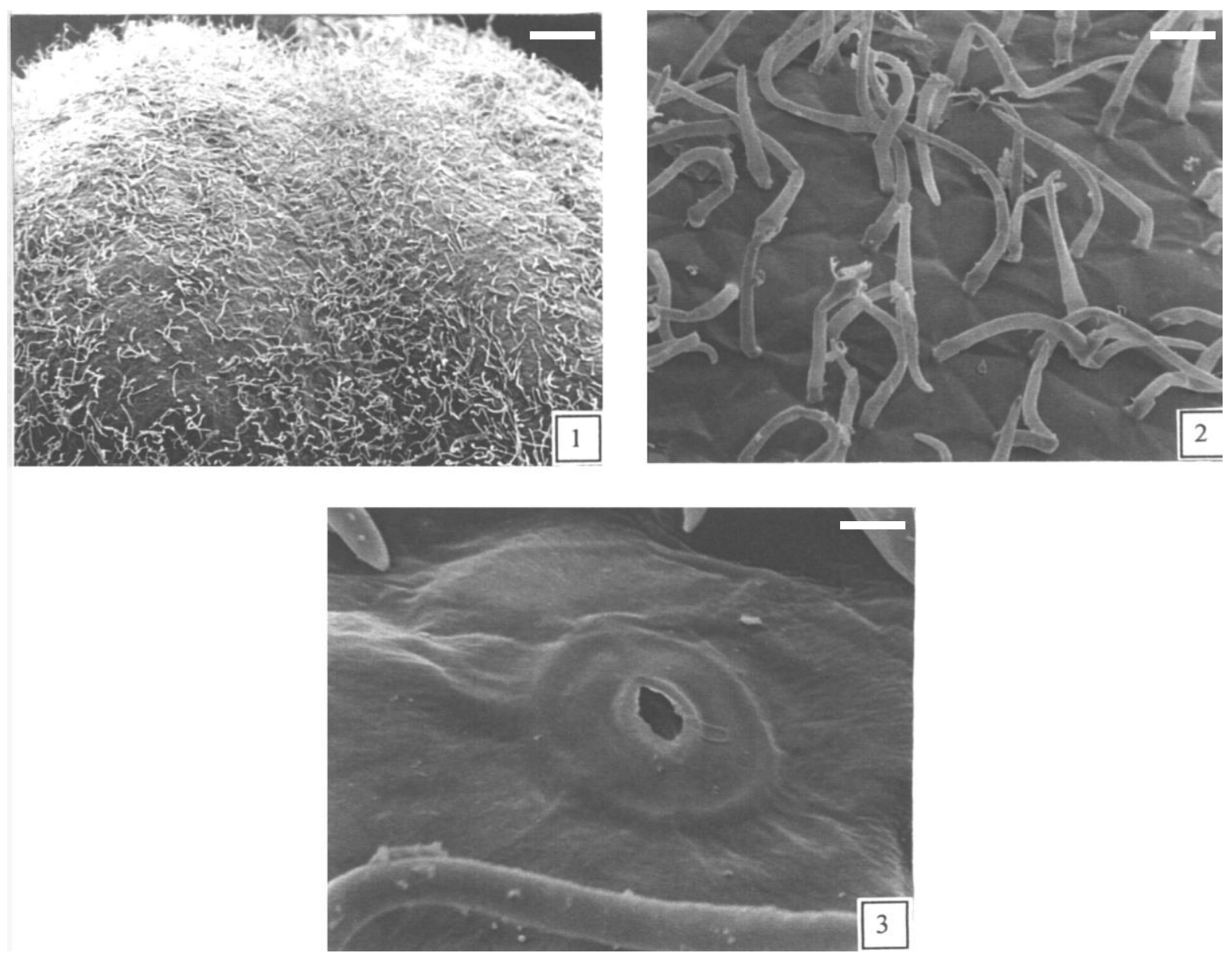
Figure 2

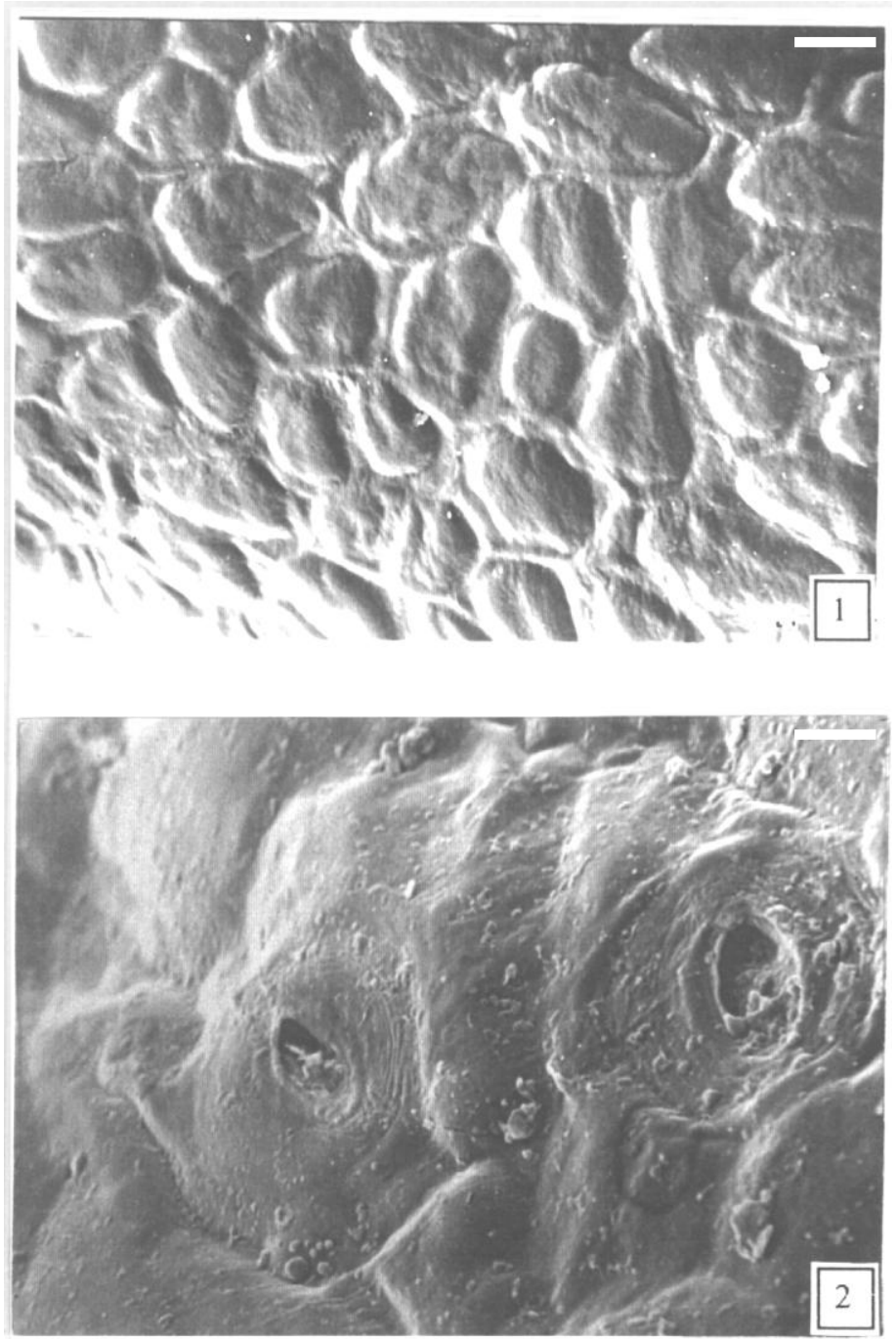


Figure 3
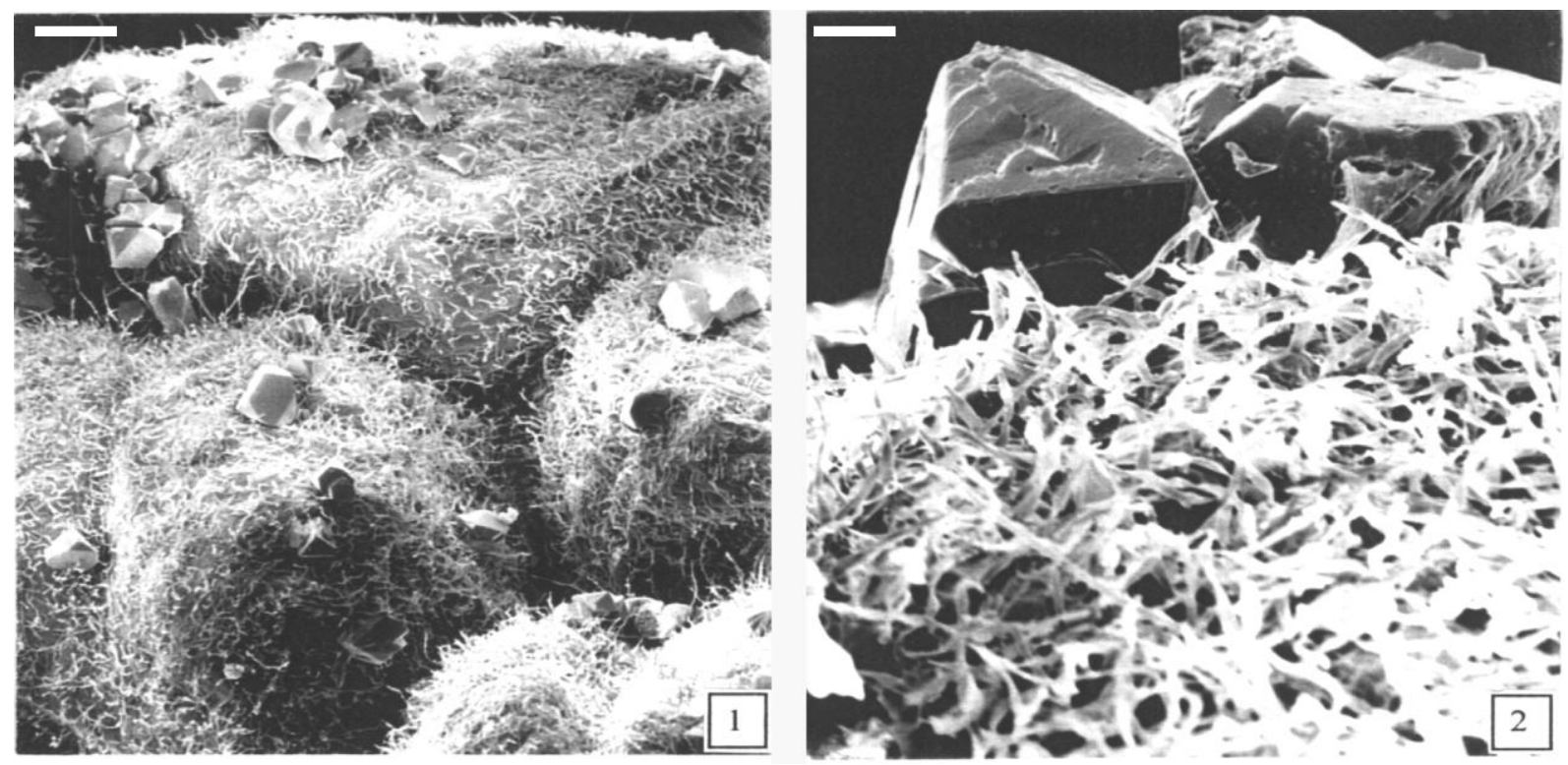
Figure 4
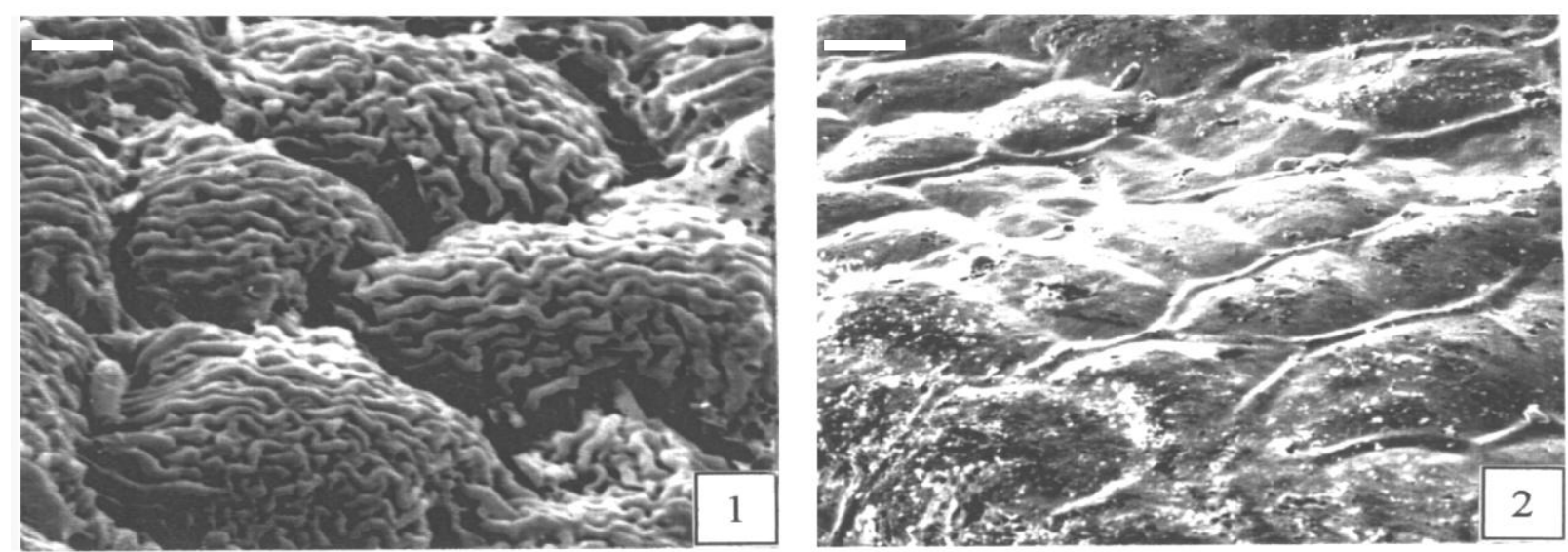

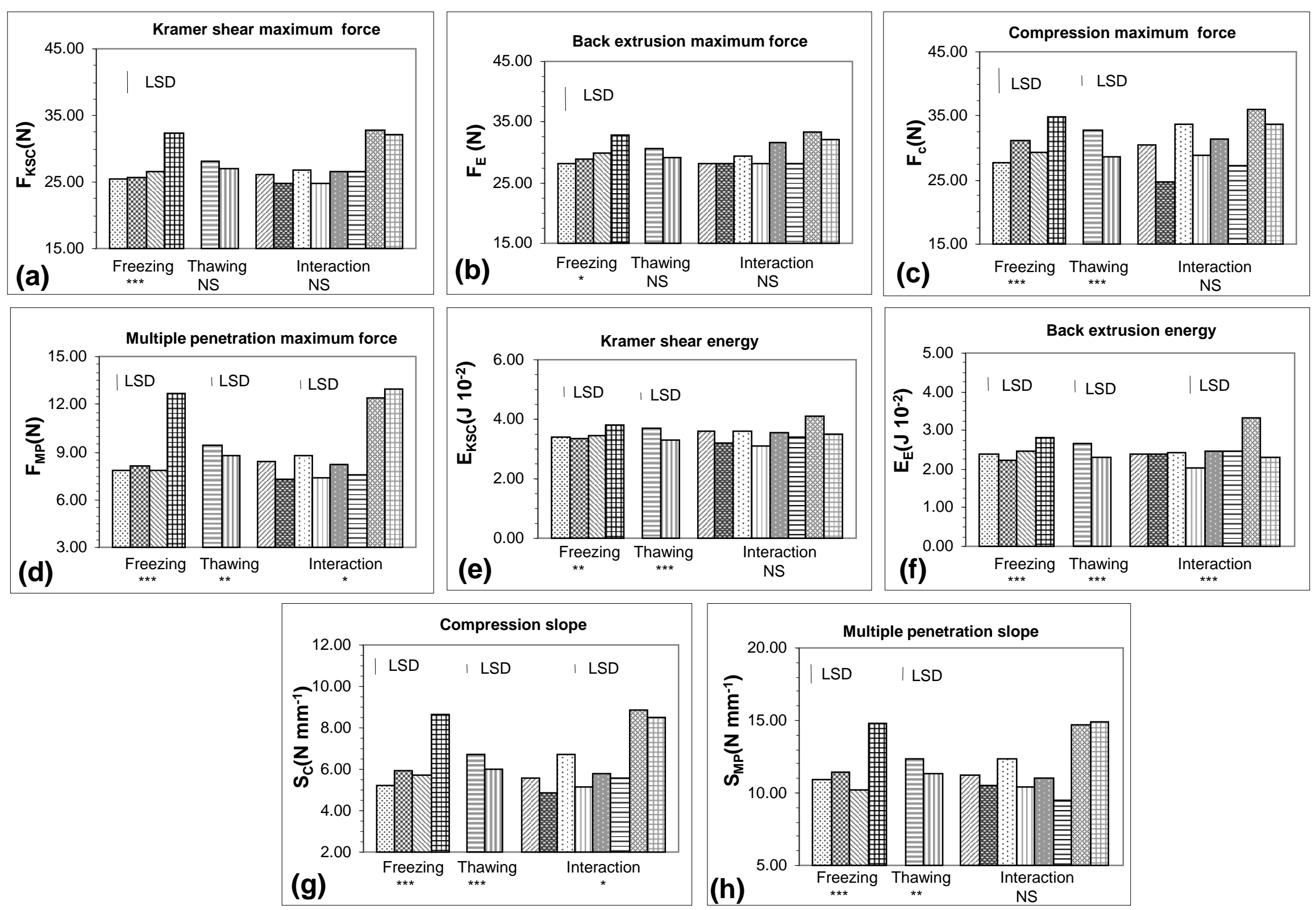

\begin{tabular}{|c|c|c|}
\hline $\begin{array}{l}R_{\mathrm{f}}=140^{\circ} \mathrm{C} \mathrm{min}^{-1} \\
\mathrm{R}_{\mathrm{f}}=2.2^{\circ} \mathrm{C} \mathrm{min}^{-1}\end{array}$ & $\begin{array}{l}\mathbf{R}_{\mathrm{f}}=32{ }^{\circ} \mathrm{C} \mathrm{min}^{-1} \\
\mathbf{R}_{\mathrm{t}}=0.12^{\circ} \mathrm{C} \mathrm{min}^{-1}\end{array}$ & $\begin{array}{l}\mathbb{R} R_{\mathrm{f}}=1^{\circ} \mathrm{C} \mathrm{min}^{-1} \\
\mathrm{R}_{\mathrm{f}}=0.04^{\circ} \mathrm{C} \mathrm{min}^{-1}\end{array}$ \\
\hline 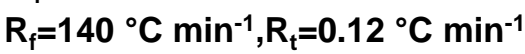 & $R_{\mathrm{f}}=140^{\circ} \mathrm{C} \mathrm{min}^{-1}, \mathrm{R}_{\mathrm{t}}=0.04^{\circ} \mathrm{C} \mathrm{mi}$ & $\mathrm{R}_{\mathrm{f}}=32{ }^{\circ} \mathrm{C} \mathrm{min}^{-1}, \mathrm{R}_{\mathrm{t}}=0.12{ }^{\circ} \mathrm{C} \mathrm{min}^{-1}$ \\
\hline $\begin{array}{l}R_{\mathrm{f}}=32{ }^{\circ} \mathrm{C} \mathrm{min}^{-1}, \mathrm{R}_{\mathrm{t}}=0.04{ }^{\circ} \mathrm{C} \mathrm{min}^{-1} \\
\mathrm{R}_{\mathrm{t}}=2.2^{\circ} \mathrm{C} \mathrm{min}^{-1}, \mathrm{R}_{\mathrm{t}}=0.12{ }^{\circ} \mathrm{C} \mathrm{min}^{-1}\end{array}$ & $\begin{array}{l}R_{\mathrm{f}}=1^{\circ} \mathrm{C} \mathrm{min}^{-1}, \mathrm{R}_{\mathrm{t}}=0.12^{\circ} \mathrm{C} \mathrm{min}^{-1} \\
\mathrm{R}_{\mathrm{f}}=2.2^{\circ} \mathrm{C} \mathrm{min}^{-1}, \mathrm{R}_{\mathrm{f}}=0.04{ }^{\circ} \mathrm{C} \mathrm{min}^{-}\end{array}$ & 目 $R_{f}=1^{\circ} \mathrm{C} \mathrm{min}^{-1}, \mathrm{R}_{\mathrm{t}}=0.004^{\circ}{ }^{\circ} \mathrm{min}^{-1}$ \\
\hline
\end{tabular}




\section{Figure 7}
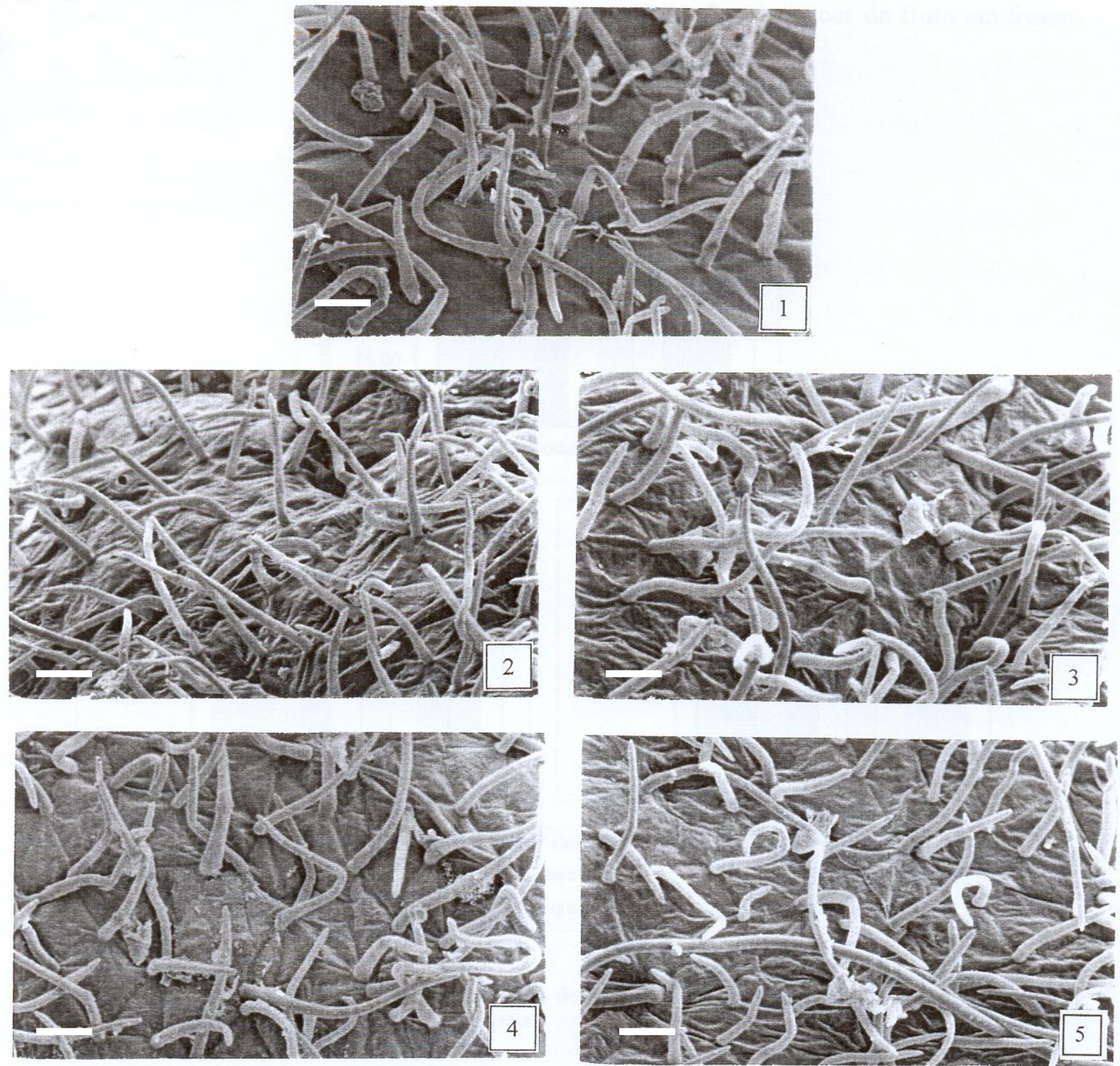


\section{Figure 8}
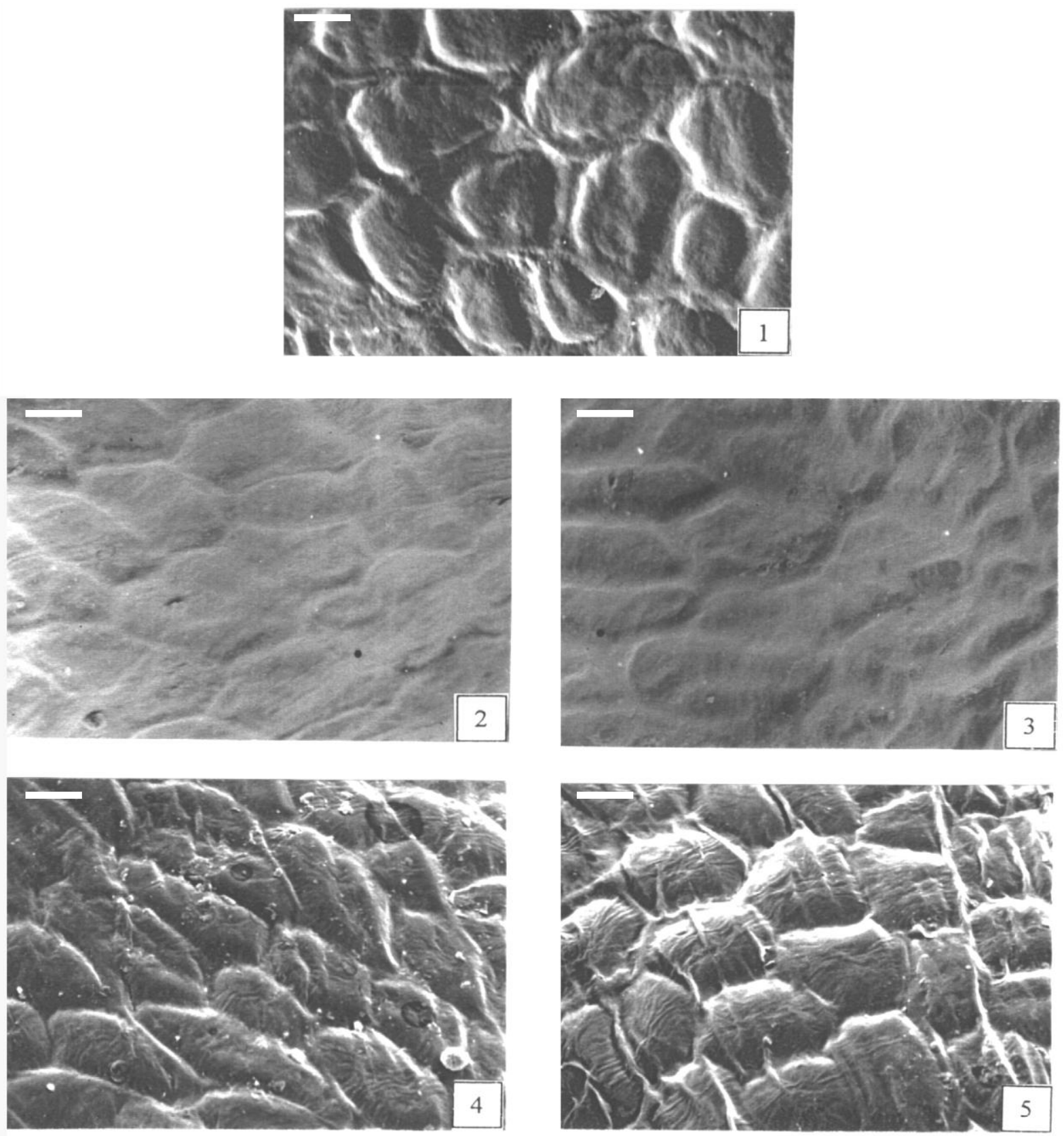


\section{Figure 9}
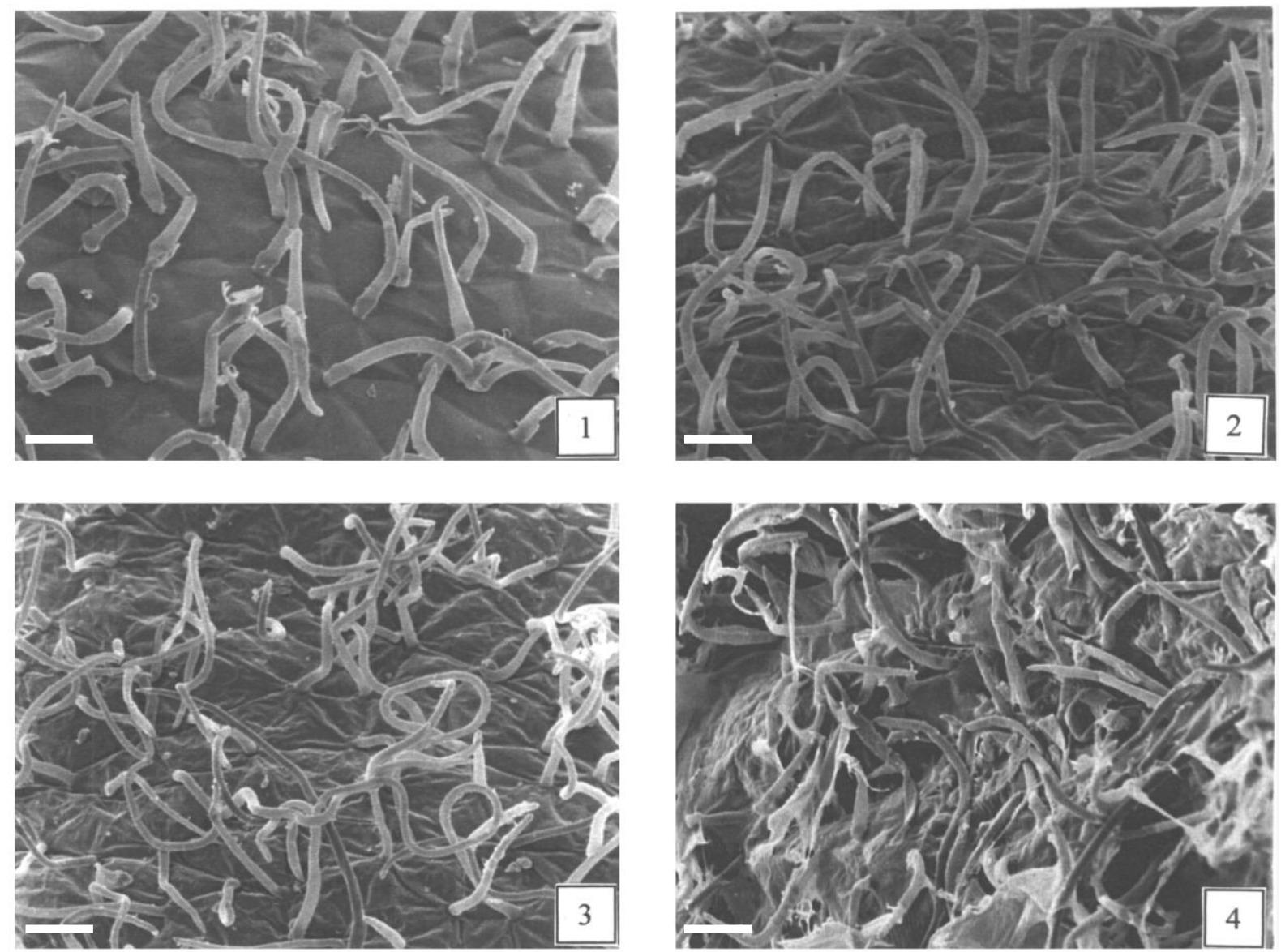


\section{Figure 10}
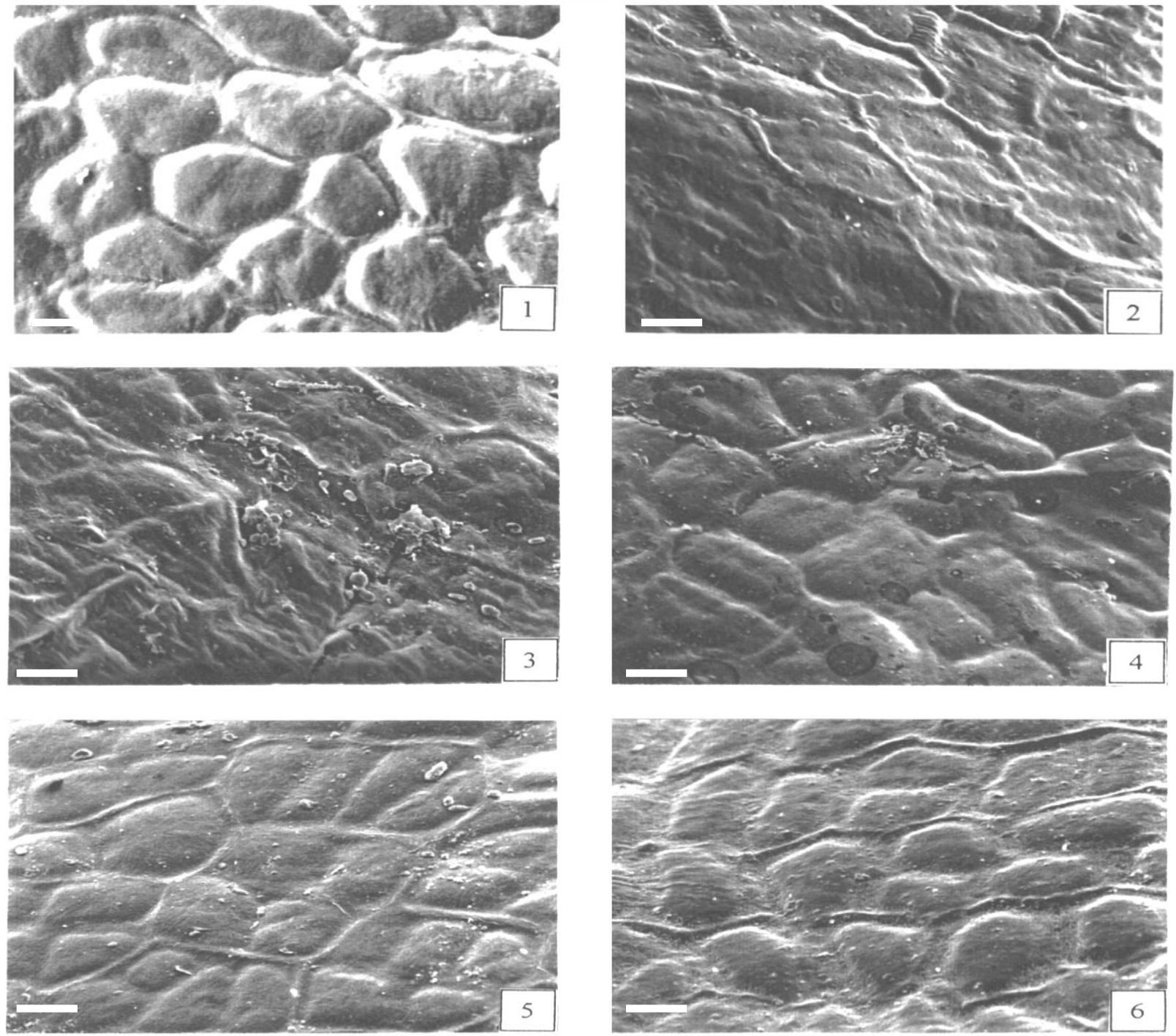